\title{
Are all types of capital flows driven by the same factors? Evidence from Mexico
}

\author{
Raul Ibarra ${ }^{3}$ Isela-Elizabeth Tellez-Leon ${ }^{1,2} \mathbb{D}$ \\ Received: 10 February 2018 / Accepted: 4 January 2019 / Published online: 9 January 2019 \\ (c) The Author(s) 2019
}

\begin{abstract}
In this paper, we analyse the impact and persistence of shocks to global (push) and domestic (pull) factors on each component of the financial account for the Mexican Balance of Payments, at the highest degree of disaggregation, including investment by foreign residents in Mexican public and private sector securities, as well as investment by domestic residents in foreign securities. To this end, we estimate impulse response functions from vector autoregressive models for the period 1995-2015. We find that an increase in the foreign interest rate leads to lower portfolio investment. An increase in global risk generates lower portfolio investment, particularly in private sector securities. Foreign investors respond to a higher extent to foreign interest rate and liquidity shocks compared to domestic investors.
\end{abstract}

Keywords Capital flows · Push factors · Pull factors · Vector autoregression

JEL Classification F21 $\cdot$ F32 $\cdot$ F41 · F47

\begin{abstract}
We thank Enrique Alberola, Nicolás Amoroso, Arturo Antón, Rodolfo Cermeño, Juan M. Contreras, Pablo Cotler, Adrián de la Garza, Gerardo Hernandez-del-Valle, Juan R. Hernández, Marco Hernández, Yoonbai Kim, Othón Moreno, Alejandro Rodríguez-Arana, Irving Rosales, Ernesto Sepúlveda, Isidro Soloaga, David Strauss, Martín Tobal, Daniel Ventosa-Santaulària and the seminar participants at Banco de México, Centro de Investigación y Docencia Económicas, Universidad Iberoamericana, the 83rd International Atlantic Economic Conference, the 70th European Meeting of the Econometric Society, and the 4th Mexico Annual Congress of Economics and Public Policy for their constructive comments. We also thank the editor and anonymous referees for their valuable comments. Andrés Jurado and Andrea Miranda provided excellent research assistance. The authors gratefully acknowledge the financial support provided by CONACYT. Dr. Tellez-Leon mainly contributed to this research while she was working at Banco de México, and she has continued working on this paper at IIASA. The views on this article correspond to the authors and do not necessarily reflect those of Banco de México or IIASA. All errors are our responsibility.
\end{abstract}

$\bowtie \quad$ Isela-Elizabeth Tellez-Leon

tellez@iiasa.ac.at; tellezelizabeth_2015@yahoo.com

Extended author information available on the last page of the article 


\section{Introduction}

The rise in capital flows to emerging economies (EMEs) after the global financial crisis of 2008-2009 has renewed the interest about the determinants of capital flows. This has occurred because of their effects on the real economy, the exchange rate and asset prices (Fratzscher 2012). Increased capital flows can affect developing economies in at least two ways. On the one hand, international borrowing allows a country to increase investment without sacrificing consumption. On the other hand, large capital flows may be followed by current account deficits, inflationary pressures and appreciation of the real exchange rates in the recipient country. The latter in turn can lead to a reduction in the trading sector. Thus, the current account may become more vulnerable to external shocks and reversals of capital flows.

This paper examines the determinants of different types of capital flows to Mexico for the period during which Mexico has followed a flexible exchange rate regime (1995-2015). The literature on capital flows has focused on two sets of factors that encourage investors to shift resources to EMEs: external or push factors and internal or pull factors (Fernandez-Arias 1996). Push factors are beyond the control of EMEs. They include foreign interest rates, international liquidity and global risk conditions. Pull factors provide information about the prevailing economic conditions in each country, such as macroeconomic stability and financial vulnerability. A better understanding by government officials of these factors is useful for the design of macroeconomic, macroprudential and financial market policies. ${ }^{1}$

The majority of the papers in the literature have analysed capital flows at a rather low level of disaggregation, including Foreign Direct Investment (FDI) and Portfolio Investment (PI) flows. For instance, Edison and Reinhart (2000), Montiel and Reinhart (1999) and De Gregorio et al. (2000) have analysed the effects of capital controls on the composition of these broad categories of capital flows. However, a more disaggregated analysis of capital flows may lead to a better understanding of their impact on the economy.

This paper contributes to the capital flows literature in two main aspects. First, we analyse the determinants of each component of the financial account at the highest

\footnotetext{
${ }^{1}$ Some empirical studies have highlighted the importance of push factors. For example, Calvo et al. (1996) and Fernandez-Arias (1996) found that the reduction in foreign interest rates explained much of the capital inflows to Latin American countries in the early 1990s. More recently, Fratzscher (2012) concluded that push factors became the main drivers of capital flows during the 2008-2009 financial crisis, while pull factors were more important onwards. Overall, this author highlights that changes in global liquidity and risk conditions have a larger effect on capital flows, with heterogeneous responses across countries, caused by differing institutional quality. Similarly, in a more recent paper, Eichengreen and Gupta (2016) have found that the relative importance of push and pull factors to explain changes in capital flows changed after 2002. In particular, push factors (especially global risk) seem to be more important compared to pull factors. Forbes and Warnock (2012) show that global factors-especially global risk—can cause extreme episodes of capital flows and note that macroeconomic features of the host country lose relative importance. For the case of Mexico, Ying and Kim (2001) find that foreign output shocks can explain more than half of capital inflows during the period 1980-1996 using a structural vector autoregressive method. Similarly, De Vita and Kyaw (2008) observe that shocks to foreign output were a key determinant of capital flows in Mexico during the period 1976-2001. On the other hand, Bohn and Tesar (1996) and Chuhan et al. (1998) conclude that macroeconomic conditions and trade connections have been the most relevant determinants of the amount of capital flows.
} 
degree of disaggregation. This is motivated by the findings of Forbes and Warnock (2012) who highlight the importance of analysing different types of capital flows, in particular, differentiating between foreign and domestic investors. The financial account can be decomposed into Portfolio Investment (PI), Other Investment (OI) and Foreign Direct Investment (FDI). ${ }^{2}$ These in turn include investment by foreign residents into Mexican public and private sector securities and investment by domestic residents in foreign securities. Analysing the determinants of capital flows at a high level of disaggregation is important because different components of the financial account might be driven by different types of factors. For instance, PI and OI tend to be more liquid than FDI; thus, they are likely to respond faster to changes in economic fundamentals. Moreover, at a higher level of disaggregation, holdings of public sector securities are directly related to interest rates. Therefore, they are more likely to be affected by interest rate shocks compared to private sector securities.

Second, this paper focuses on Mexico, which is an interesting case of study considering the large volume of capital inflows following the trade liberalization in the $1990 \mathrm{~s}$ and more recently in the aftermath of the 2008-2009 financial crisis. ${ }^{3}$ That is, the global financial crisis was followed by a period of low interest rates in advanced economies and increased liquidity in international markets. This in turn increased capital flows to EMEs in general and Mexico in particular, as international investors were searching for high yields in those economies. In addition, the trading volume of Mexican government securities is one of the highest among emerging markets (García-Padilla 2014). ${ }^{4}$ The sample used in this study covers the period 1995-2015, during which Mexico has followed a flexible exchange rate regime. Thus, our sample includes data during and after the global financial crisis, while most of the literature has focused on an earlier period. This period is of particular interest because of the dramatic increase in capital flows after the global financial crisis (Fratzscher 2012).

To analyse the determinants of capital flows in the short and medium terms, we employ a vector autoregressive (VAR) model. This is an important departure from the literature on this subject that uses panel models. The panel models are useful to obtain the contemporaneous mean effect for a group of countries of push and pull factors on capital flows. However, there could be important differences between those countries and heterogeneity in the timing of the response of capital flows to various shocks. To analyse the case of Mexico in particular, we follow a VAR model, which allows us to

\footnotetext{
2 Other Investment is a residual category that includes bank loans, trade credits and other flows that are not included in PI or FDI.

3 Emerging economies have increased their participation in the design of international financial reforms. Mexico, in particular, has become a member of the Basel Committee. This has been associated with two important factors (Chiquiar and Tobal 2016). First, Mexico has attained experience in the design of the financial regulations after being involved in financial crises in the past. Second, recent literature shows that global financial conditions including the increase in liquidity after the financial crisis and the subsequent increase in capital flows are important determinants of domestic financial variables such as credit growth (Bruno and Shin 2015). In turn, capital flows can provide useful information to construct output gap estimates that are more robust compared to traditional estimates that exclude information on capital flows (Chiquiar and Tobal 2017).

4 For instance, according to a survey conducted by the Emerging Markets Traders Associations, in the second and third quarters of 2016 the trading volume of Mexican government securities was the second highest among emerging markets after India (Murno 2016).
} 
examine the dynamic impact on capital flows of different shocks on capital flows. In this way, we analyse the impulse response functions (IRF) of each component of the financial account to domestic and foreign shocks. The push factors we examine are global risk, U.S. liquidity, U.S. GDP and U.S. interest rate. Regarding pull factors, we consider domestic GDP, interest rate, inflation and exchange rate.

We find that shocks to global risk and the Federal Funds rate (FFR) have an impact on several items of PI and OI. In particular, increases in global risk or foreign interest rates tend to be associated with lower capital flows in PI and OI to Mexico, as most investors are risk averse and prefer to invest abroad when foreign interest rates are higher. The effects of foreign interest rate shocks on these items seem to be highly persistent. Foreign interest rate and liquidity shocks have important effects on PI by foreign investors, but not on PI by domestic investors. In contrast to the responses of PI and OI, the FDI components seem to respond less to push factors, as their responses in general are not statistically significant. That is, PI and OI seem to respond to a higher extent to short-term shocks compared to FDI, which possibly occurs because they tend to be more liquid than FDI. In addition, we find that domestic conditions also play a role to explain movements in capital flows. For instance, we find that higher GDP growth leads to higher PI, while higher interest rates and lower inflation generate higher inflows of OI.

We bring evidence to the literature that underlines benefits from analysing disaggregated flows, because in several cases only some of the disaggregated components respond to the shocks. For instance, a shock to the FFR has important effects on PI in public sector securities by foreign residents. This can be explained because public securities are the closest substitutes to U.S. Government bonds found in the Mexican financial market. In addition, we find that holdings of private sector securities by foreign investors decrease after a rise in global uncertainty, while their holdings of public sector securities present an opposite response. This may take place if foreign investors move their capital away from riskier securities into relatively safer assets after the shock in global uncertainty, that is, a flight to quality effect. Furthermore, our results indicate that only foreign investors respond to shocks in foreign interest rates and foreign liquidity, as opposed to domestic investors. Finally, we find that shocks to domestic and U.S. interest rates have important effects on the demand for public sector securities.

The remainder of this paper is organized as follows. In Sect. 2, the stylized facts of capital flows in Mexico are briefly reviewed. The VAR model and the empirical results for both broad and disaggregated categories are presented in Sect. 3. The last Section concludes and discusses areas for future research.

\section{Stylized facts of capital flows}

In the last decade, episodes of increases in net capital flows to Mexico began with the recovery of global markets in mid-2009 and have continued, although intermittently, until the present. Figure 1 shows the net inflows in the financial account as a share of Mexican GDP (four-quarter moving average). Although the most important compo- 
Fig. 1 Net capital flows, 1995-2015. As a proportion of the Mexican GDP (s.a). Moving average (4 quarters). Source: Own elaboration with data from Banco de México

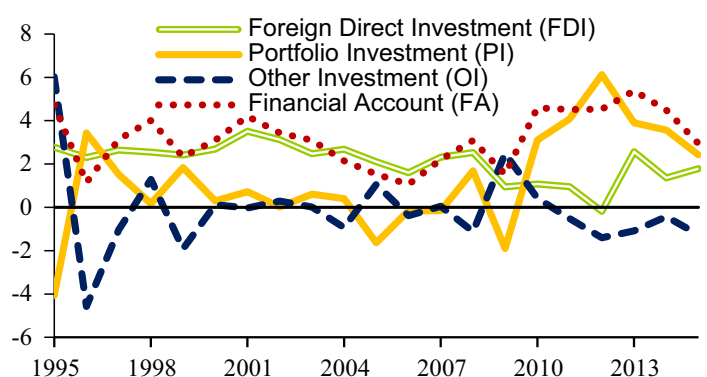

nent of the financial account during the period 1995-2009 was FDI, ${ }^{5}$ PI flows have become comparatively more relevant in recent years. ${ }^{6}$

We notice that FDI presents nearly a constant dynamic, while PI and OI show a larger volatility and are negatively correlated, especially after 2009. Movements in PI seem to have important effects on the dynamics of the financial account. As PI seems to present larger variation over time and it is relatively liquid compared to FDI, we would expect that PI responds largely to shocks. Larger resources allocated to PI in relation to FDI reflect higher levels of investors' confidence in the Mexican economy in the short term. For the case of Mexico, PI flows have been more volatile than FDI. Recent international evidence shows important net flows to large emerging economies, and these have become generally more volatile. ${ }^{7}$ In Asia and Latin America, especially in 2010, net flows have been above the pre-crisis average (see OECD 2013b). This is largely explained by the growth of PI from 2010 onwards, as the low interest rate environment in advanced economies following the crisis generated a search for yield effect.

The dynamics of gross PI, that is, PI by foreign investors in domestic securities and PI by domestic investors in foreign securities, are depicted in Fig. 2. During the period 2009-2012, a positive trend is apparent in the data. PI by foreign investors shows a similar trend as net PI. ${ }^{8}$ In 2013, PI was nearly twice as large as FDI to Mexico, which can be associated with confidence in Mexican bonds (UNCTAD 2013). However, starting from 2013 when the Federal Reserve announced the possibility of reducing the unconventional monetary policies used to stimulate the economy after the financial crisis (that is, the tapper tantrum), PI flows show a downward trend. The increase in the purchase of government bonds by non-residents has increased foreign investors' accounts in domestic banks denominated in U.S. dollars. Although this type

\footnotetext{
5 FDI is a category of cross-border investment made by a foreign investor in a domestic company, with the objective of establishing a lasting interest (OCED 2013a).

$6 \mathrm{PI}$ is defined as cross-border transactions and positions involving foreign currency, securities, debt, equity and other categories. The data shows that PI flows are part of the financial portfolio of non-residents and can be found on the stock market or in the money market.

7 Net capital flows are defined as the sum of gross inflows and outflows, where outflows have a negative sign (IMF 2003).

8 In our data, an increase in PI either by foreign or domestic investors implies higher net capital inflows. That is, PI by foreign investors raises when those investors increase their holdings of domestic securities, and PI by domestic investors increases when those investors decrease their holdings of foreign securities. The same applies for OI by foreign and domestic investors.
} 
Fig. 2 Gross capital flows, 1995-2015. As a proportion of the Mexican GDP (s.a). Moving average (4 quarters). Source: Own elaboration with data from Banco de México

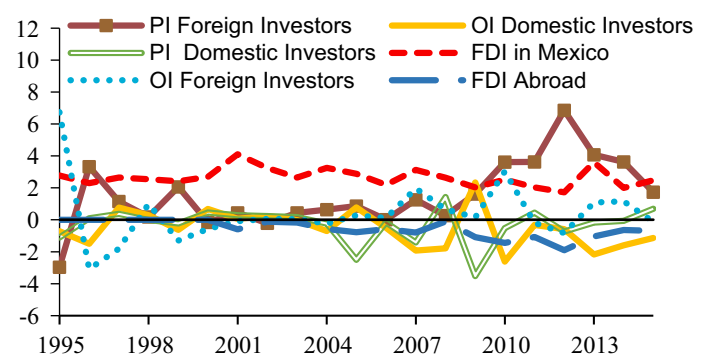

of investment might imply a risk of external shocks, in the short term, Mexico has been able to mitigate those risks. In particular, Mexico has qualified for the IMF's Flexible Credit Line for about US\$88 billion, based on the country's strong economic fundamentals and policy framework. This has improved investors' confidence, together with the accumulation of international reserves of around US\$182 billion (Banco de México 2016).

Figure 2 also displays the behaviour for gross OI flows. OI consists of those components of the financial account such as capital flows into bank accounts (direct credits from commercial banks) or holdings of metals. As can be seen, the series exhibit an important degree of volatility. Specially, we observe that the behaviour of foreign investors and domestic investors present a negative correlation during the period of analysis. ${ }^{9}$ The net flow of OI since 2010 shows a downward trend, which may be associated with higher risk aversion after the crisis. As FDI is a long-term investment, it has lower volatility than the other components of the financial account. In this sense, FDI generates long-term funding relationships and transmission of technology as a result of profit maximization by the foreign enterprises. Thus, FDI typically refers to long-term capital investment, such as the purchase of machinery, buildings or manufacturing plants.

The time series for gross FDI are also illustrated in Fig. 2. The net balance of direct investment reflects more closely the behaviour presented by foreign investment in Mexico. There is a gap between the series at the end of 2009, which is a result of the negative trend observed in the FDI abroad. According to the World Investment Report of the United Nations Conference on Trade and Development (UNCTAD 2015), the global corporate executives' outlook for the best investment locations worldwide includes China, USA, India, Brazil, Singapore, UK, Germany, Hong Kong and Mexico. According to the UNCTAD business survey forecast, Mexico will receive $6 \%$ of total global FDI flows for 2015-2017.

In the next section, we will present a VAR model to analyse the determinants of capital flows. In particular, this model will be used to estimate the response of different types of capital flows to shocks in pull and push factors.

\footnotetext{
9 A negative correlation can occur when global conditions have a synchronizing effect on the investment in foreign and domestic securities. For instance, if higher global risk leads to lower investment in domestic securities by foreign investors and lower investment in foreign securities by domestic investors, this will generate a negative correlation between OI by foreign and domestic investors.
} 


\section{Econometric analysis}

In order to analyse the determinants of capital flows to Mexico, a Vector Autoregression (VAR) model is estimated. This model has been widely used in the literature to analyse the impact of various factors on capital flows in emerging economies (e.g. Ying and Kim 2001; Çulha 2006; De Vita and Kyaw 2008). Both external and internal shocks that affect capital flows are included in this model. Calvo et al. (1993) and FernandezArias (1996) find that interest rates and economic activity in the USA are among the main external factors that influence capital flows. We also consider shocks to internal factors, such as shocks to output and domestic interest rates. The importance of those types of factors is explained in Calvo et al. (1993) and Lensink and White (1998). Unlike a univariate model, the VAR model considers the feedback effects among the variables included in the system.

\subsection{Description of variables}

In this subsection, we present the description of variables included in the model used to analyse the effects of the main determinants of capital flows in Mexico. The set of endogenous variables consists of those commonly used to model capital flows to emerging economies. We analyse 22 components of the financial account. The broad categories we analyse are FDI, PI and OI. In turn, each of these components contains foreign and domestic investors' flows. PI and OI by foreign investors in turn include investment in public and private sector securities. Table 1 provides a brief definition of each component of the financial account. The data includes the period comprising the first quarter of 1995 to the fourth quarter of 2015. Pull factors include domestic GDP, the overnight interest rate for Mexico, domestic inflation and the nominal pesodollar exchange rate. ${ }^{10}$ Push factors include the VIX index, M1, the U.S. FFR and U.S. GDP. We use the VIX as a proxy for global uncertainty. ${ }^{11}$ The FFR is used as an indicator of U.S. monetary policy. We include U.S. M1 as a proxy for global liquidity. This variable accounts for the unconventional monetary policies implemented after the global financial crisis, which in turn are linked to higher money supply (Bernanke and Reinhart 2004). Finally, we include U.S. GDP as a proxy for foreign economic activity. ${ }^{12}$ We also include the oil price as an exogenous variable. Real GDP in Mexico is expressed in 2003 pesos, and real U.S. GDP and real capital flows are expressed in 2003 U.S. dollars.

The data are obtained from the Federal Reserve (the FFR and U.S. M1), Bureau of Economic Analysis (U.S. real GDP), Banco de México (capital flows, the overnight interest rate for Mexico and the exchange rate), the National Institute of Statistics and Geography (real Mexican GDP and Consumer Price Index of Mexico) and Bloomberg (VIX and oil price).

\footnotetext{
10 In particular, we use the bank funding rate, a representative interest rate on operations by banks and brokerage firms in the wholesale market.

11 The VIX is a measure of expected financial volatility implied by the S\&P 500 index options.

12 We have also used alternative measures of global economic activity including the GDP for the Euro Area. The results are similar to those reported in this paper.
} 
Table 1 Definitions of the financial account. Source: IMF (2003)

This account contains transactions associated with changes of possession
in external financial by domestic and foreign investors. The financial
account is divided into Foreign Direct Investment, Portfolio Investment
and Other Investment by domestic and foreign investors

Portfolio investment

Foreign investors

Public sector

Securities issued abroad

Money market

Private sector

Securities issued abroad

Stock market and money

Domestic investors

Other investment

Foreign investors

Public sector

Development banks

Non-banking sector

Private sector

Business banking

Non-banking sector

Domestic investors

Foreign direct investment

In Mexico

Abroad
This account includes equity securities and debt securities in the form of bonds, money market instruments and financial derivatives such as options

Foreign holdings of equity securities and debt securities issued by entities in the country. Debt securities are in turn divided into bonds, money market instruments and financial derivatives

It consists of holdings by foreign residents of securities issued by the public sector

It contains securities issued abroad by the public sector

Includes government bonds, IPAB bonds, among others

Foreign investors' flows in this account are originated by foreign investment in stock market, money market and the issuance of securities abroad

It contains securities issued abroad by the private sector

It includes commercial and financial paper, negotiable certificates of deposit and short-term notes

Holdings by Mexican residents of securities issued by foreign entities

Residual category that includes all financial transactions not covered under direct investment, portfolio investment or reserve domestic investors. Other investment includes trade credits, loans and deposits

Obligations that are not recorded in the FDI or PI. For example, when the foreign bank makes a loan to a domestic borrower, it would take a plus sign. Similarly, when a resident repays the principal on a loan to a foreigner it takes a minus sign

Foreign investors' flows of the public sector, for example net loans that have received the public sector non-bank entities (Pemex, CFE and Federal Government)

Foreign holdings of securities issued by the development bank

Foreign holdings of securities issued by the non-banking sector

Foreign holdings of securities issued by the private sector

Foreign holdings of securities issued by domestic commercial banks

Foreign securities issued by the non-banking sector

Loans made by domestic banks to foreigners. For example, when a domestic bank makes the loan to the foreigner it would take a negative sign. Similarly, when a foreigner repays the principal on the loan it takes a plus sign. The loan is the domestic bank's asset and the foreigner's liability

It consists of domestic and foreign investors' flows between a non-resident direct investor and a resident company

Flows of foreigners to a domestic country

Flows of residents to a foreign country 


\subsection{VAR model}

The reduced form representation of the model is:

$$
\boldsymbol{y}_{t}=\boldsymbol{c}+\boldsymbol{A}(L) \boldsymbol{y}_{t-1}+\boldsymbol{B}(L) \boldsymbol{x}_{t}+\boldsymbol{u}_{t}
$$

where $\boldsymbol{y}_{t}=\left[\log \mathrm{VIX}_{t}, \Delta \log M_{t}^{*}, \Delta \log Y_{t}^{*}, R_{t}^{*}, \Delta \log Y_{t}, R_{t}, \Delta_{4} \log P_{t}, \Delta \log e_{t}, F_{t}\right]$; $\boldsymbol{x}_{t}=\Delta \log P_{t}^{\text {Oil }} ; \boldsymbol{c}$ is a vector of constants; $\boldsymbol{u}$ is a vector of residuals whose residual covariance matrix is $\boldsymbol{\Omega}$; and $\boldsymbol{A}(L)$ and $\boldsymbol{B}(L)$ are polynomial matrices in the lag operator $L$. The VIX Index is a proxy for global risk. $M_{t}^{*}, Y_{t}^{*}, R_{t}^{*}$ represent real M1, real GDP and the FFR in the USA, respectively; whereas $Y_{t}, R_{t}, P_{t}, e_{t}, F_{t}$ represent real GDP, the overnight interest rate, the consumer price index, the peso-dollar FIX exchange rate ${ }^{13}$ and capital flows as proportion of Mexican GDP, respectively. The variables $P_{t}, M_{t}^{*}$ are seasonally adjusted with the X12-ARIMA method, while $Y_{t}$ and $Y_{t}^{*}$ are reported as seasonally adjusted by their respective statistical offices. ${ }^{14}$ We take $\log s$ and first differences as necessary to achieve stationarity. The results of the unit root tests are available from the authors upon request. The Bayesian information criterion (BIC) was used to assess the number of lags to be included in the model, in order to adequately capture the dynamics of the system while remaining parsimonious. The optimal lag length turned out to be one.

The estimated residuals from the reduced form model are linear combinations of structural shocks. Thus, it is necessary to impose assumptions to identify the structural shocks. To that end, the residuals $\boldsymbol{u}$ are orthogonalized using a Cholesky decomposition of the covariance matrix $\boldsymbol{\Omega}$ to produce structural innovations $\boldsymbol{\varepsilon}$, as follows:

$$
C \varepsilon_{t}=\boldsymbol{u}_{t}
$$

where $C$ is the lower triangular Cholesky matrix, with ones in its main diagonal. ${ }^{15}$

Thus, the mechanism used to identify the shocks is recursive. For the first variable in the VAR, the term of the structural shock is given by $\varepsilon_{1 t}=u_{1 t}$. For the variable $j>1$, the corresponding structural shock is given by $\varepsilon_{j t}=u_{j t}-c_{j, 1} \varepsilon_{1 t} \ldots-c_{j, j-1} \varepsilon_{j-1, t}$, where $c_{j, t}$ corresponds to the elements of the Cholesky matrix $\boldsymbol{C}$. In short, the variables are ordered according to their degree of exogeneity. Thus, foreign variables are contemporaneously affected only by shocks to foreign variables, while domestic variables are affected by both domestic and foreign shocks. These assumptions allow us to retrieve the structural shocks vector.

Using the recursive VAR to identify shocks has some major advantages. In particular, this approach allows incorporating the feedback relationships among the variables

\footnotetext{
13 The FIX exchange rate is an average of wholesale's market prices for operations payable in $48 \mathrm{~h}$, and it is published by Banco de Mexico.

14 Although the U.S. inflation rate may be relevant to explain capital flows, this variable is not included in our benchmark specification as the exchange rate depreciation may already capture the differences between domestic and foreign inflation rates (according to the power purchasing parity condition). In addition, we avoid a loss in degrees of freedom by having a lower number of variables in the model.

15 The positive definite symmetric matrix $\boldsymbol{\Omega}$ can be decomposed into a lower triangular matrix $\boldsymbol{C}$ and a diagonal $\boldsymbol{D}$ such that $\boldsymbol{\Omega}=\boldsymbol{C} \boldsymbol{D} \boldsymbol{C}^{\prime}$. This decomposition produces uncorrelated error terms by construction, i.e. $E\left[\varepsilon_{t} \varepsilon_{t}^{\prime}\right]=D$.
} 
Table 2 Size of one standard deviation shocks to push and pull factors

\begin{tabular}{|c|c|c|c|c|c|c|c|}
\hline \multicolumn{4}{|c|}{ Push factors } & \multicolumn{4}{|c|}{ Pull factors } \\
\hline $\begin{array}{l}\text { Global } \\
\text { risk level } \\
\text { (proxy } \\
\text { VIX) }\end{array}$ & $\begin{array}{l}\text { Global } \\
\text { liquidity } \\
\text { (proxy } \\
\text { M1) }\end{array}$ & U.S. GDP & $\begin{array}{l}\text { U.S. } \\
\text { Interest } \\
\text { rate }\end{array}$ & $\begin{array}{l}\text { Mexican } \\
\text { GDP }\end{array}$ & $\begin{array}{l}\text { Mexican } \\
\text { interbank } \\
\text { interest } \\
\text { rate }\end{array}$ & Inflation & $\begin{array}{l}\text { Exchange } \\
\text { rate }\end{array}$ \\
\hline 18.05 & 1.02 & 0.44 & 0.33 & 0.74 & 1.87 & 0.73 & 2.62 \\
\hline
\end{tabular}

The variables used in the VAR model are: the VIX index, the growth rate of U.S. M1, the growth rate of U.S. GDP, the FFR, the growth rate of Mexican GDP, the interbank interest rate, the Mexican inflation, the growth rate of exchange (FIX) and the net balance of the financial account. Since the variables are expressed in logs (except for interest rates), the shocks are measured in percentage points

included in the model. In addition, with a VAR model we can obtain the dynamic responses of capital flows to different shocks. An important advantage of using an impulse response analysis instead of using a Granger causality approach is that the former allows us to examine the magnitude and direction of the response of capital flows to different shocks; thus, it provides further useful information about the effects of these shocks. Furthermore, to take into account potential long-term relationships, we estimate a VAR model in levels. We find that the results are similar to those reported here. Moreover, we examine the sensitivity of the results to various orderings. We observe that, as the contemporaneous correlation between the residuals is small, our results are robust to different orderings. ${ }^{16}$ The impulse response functions to analyse the effects of push and pull factors on net capital flows and the disaggregated capital flows are presented in the next section.

\subsection{Responses of portfolio investment, foreign direct investment and other investment to push and pull factors}

Using the VAR model explained in the previous section, the impulse-response functions are estimated to analyse the effects of push and pull factors on capital flows. In all cases, the size of the shock is one standard deviation. Table 2 presents the magnitude of each shock. Responses are presented for time horizons of 8 quarters with $90 \%$ confidence intervals. For all figures, the shocks occur at period 1. Since capital flows are expressed as a share of domestic GDP, the units of the impulse response functions are also measured as percentage points of domestic GDP. As these units are the same for all cases, they will be sometimes omitted when describing the results. Although the data start from the first quarter of 1995 , the effective estimation sample starts in the second quarter of 1996 due to data transformations and the inclusion of lags in the model. The Monte Carlo method is employed to estimate the standard errors of the impulse-response functions using 10,000 repetitions.

The estimated VAR models are stable as the inverse roots of the characteristic polynomial have modulus less than one and lie inside the unit circle. Furthermore, the null

\footnotetext{
16 The only correlation between the residuals that is greater than 0.5 occurs between the VIX and the exchange rate.
} 
hypothesis of no serial correlation of the residuals cannot be rejected according to the LM test statistic for residual correlation up to order 8. Although the discussion is focused on the responses that are statistically significant, we also describe the impulse response functions that are not significant, as this may also be informative for policymakers. The analysis is presented as follows. First, we show the IRF of PI to push and pull factors. Then, we present the same analysis for OI and finally for FDI. ${ }^{17}$

The effects of push factors on net PI can be seen in Fig. 3. In particular, this figure presents the impulse-response functions of net PI as a share of Mexican GDP to one standard deviation shocks in the VIX index, global liquidity, U.S. GDP and the U.S. interest rate. Regarding the shock to the VIX index, we would expect higher uncertainty to be followed by lower capital flows, since investors tend to be risk averse. We find that a one standard deviation shock to the VIX index, representing an increase in global risk, is followed by a decrease of 0.51 percentage points of Mexican GDP (p.p. of GDP) in net PI, a quarter after the shock occurs. The same shock has a negative effect on foreign investors' PI of around 0.82 p.p. of GDP, in the first period, as well as a positive effect of 0.70 on domestic investors' PI at the same quarter of the shock. ${ }^{18}$ As explained before, these results imply that foreign investors decrease their holdings of domestic securities and domestic investors reduce their holdings of foreign securities. Also, this shock has a negative response of 0.46 on the domestic investors' PI, at the second quarter. These results are consistent with Ahmed and Zlate (2014), who among other key findings highlight the importance of global risk as a determinant of capital flows.

The second analysed shock is US M1, which serves as a proxy for global liquidity. An increase in liquidity is expected to increase foreign investment flows to the rest of the world. Therefore, we would expect capital flows to increase after the shock in liquidity, particularly by US residents. According to the impulse-response function, net PI flows show a contemporaneous increase of 0.99 after a one standard deviation liquidity shock. Similarly, we observe a rise of 0.61 in foreign investors' PI (see Fig. 3), and the response of domestic investors is not significant. These results contrast with those from Ahmed and Zlate (2014), who do not find significantly positive effects of unconventional U.S. monetary expansion (US liquidity shock) on total net inflows to EMEs.

The next shock to be analysed is the US GDP. Although we would expect higher PI by foreign investors after the positive shock in the US GDP, their response is not significant, perhaps because they increase their investment in US rather than Mexican securities. We note, as well, that the same shock has no significant effect on the net investors' PI. A one standard deviation positive shock to the US GDP growth is associated with a 0.53 increase in domestic investors' PI, one quarter after the shock

\footnotetext{
17 Following previous literature on the determinants of capital flows, reserve assets are excluded from the analysis. As opposed to FDI, PI and OI, which consist of transactions that are originated in the market, international reserves are operated only by the central bank to finance trade imbalances, to influence the exchange rate, maintain confidence in financial markets or other motives.

18 The VAR model used to estimate the responses shown at the middle and bottom part of the figure includes PI by both foreign and domestic investors at the same time to allow for possible feedback effects between those types of flows. This approach will also be followed for the responses of OI and FDI presented later.
} 


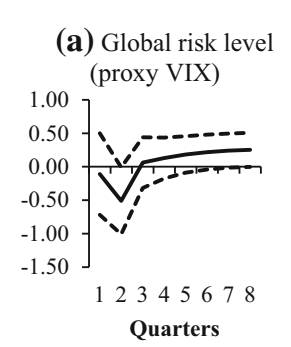

(e) Global risk level (proxy

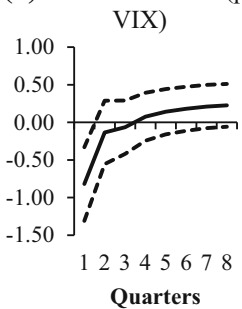

(i) Global risk level (proxy VIX)

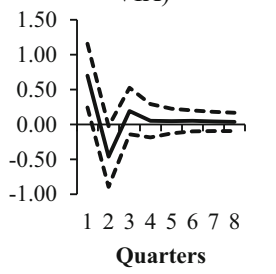

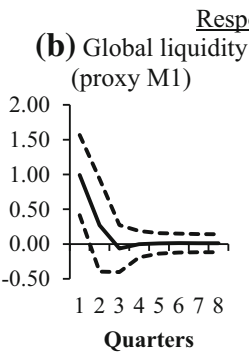

Response of PI

(c) U.S. GDP

(d) U.S. Interest rate

$\underline{\text { Response of PI by foreign investors }}$

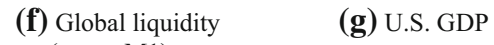
(proxy M1)

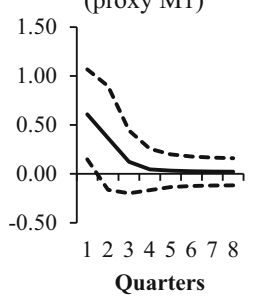

Response of PI by domestic investors
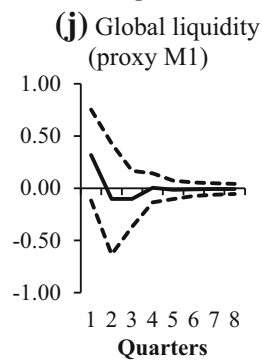

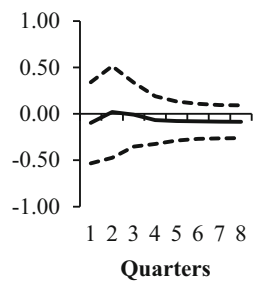

(k) U.S. GDP
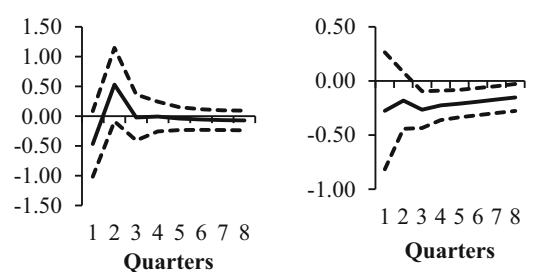

(h) U.S. Interest rate

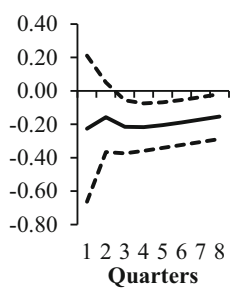

(I) U.S. Interest rate

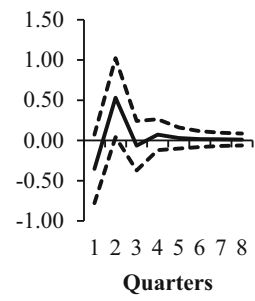

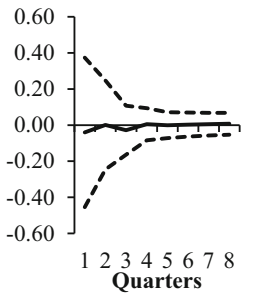

Fig. 3 Effect of shocks to push factors on the components of PI. 90\% confidence intervals. Sample: 1996 Q02-2015 Q04 (percent). Note: The variables used in the VAR model are: the VIX index, the growth rate of U.S. M1, the growth rate of U.S. GDP, the FFR, the growth rate of Mexican GDP, the interbank interest rate, the Mexican inflation, the growth rate of exchange (FIX) and capital flows

occurs. These results suggest that the dynamics of net PI inflows to external shocks in economic activity is mainly driven by the response of domestic investors' flows.

Regarding the US interest shock, we find that higher foreign interest rates lead to lower capital flows to Mexico as investors search for higher returns in US assets. The IRF of net PI flows depicts a reduction of 0.20 (average from the third to the eighth period) in response to a one standard deviation in the US interest rate. The responses of PI to the interest rate shock are persistent, as they are significant for more than 1 year. This response is explained by the behaviour of foreign investors' flows, which decrease by about 0.19 (average from the third to the eighth period). That is, foreign investors reduce their investment in domestic securities, which can be explained by the increase in the opportunity cost of maintaining domestic investments. This result is in line with that from Çulha (2006), who finds that for the case of Turkey, push 
(a) Mexican GDP

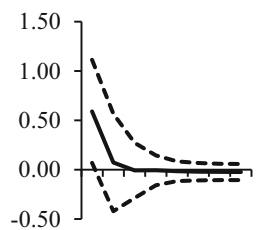

12345678 Quarters

(e) Mexican GDP

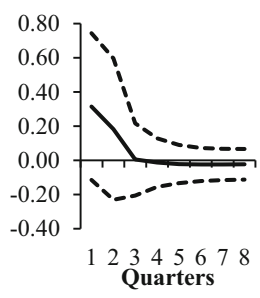

(i) Mexican GDP

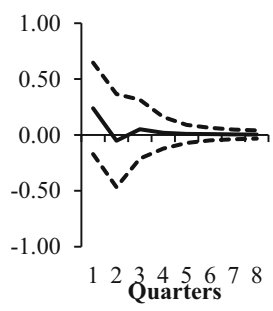

Response of PI

(b) Mexican interbank interest rate

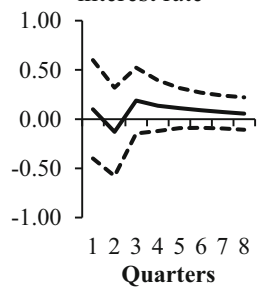

(c) Inflation

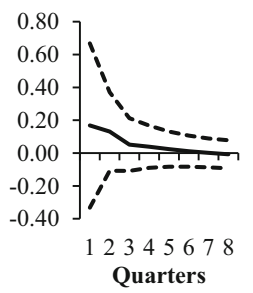

Response of PI by foreign investors

(f) Mexican interbank interest rate

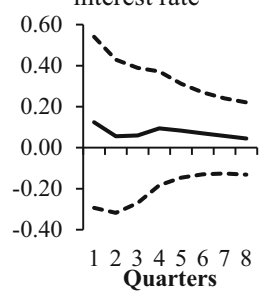

(g) Inflation

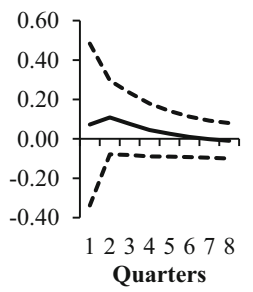

Quarters

Response of PI by domestic investors

(j) Mexican interbank interest rate

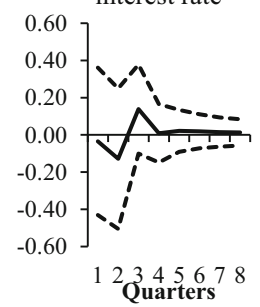

(k) Inflation

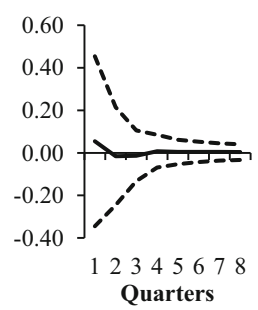

(d) Exchange rate

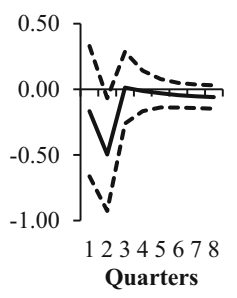

(h) Exchange rate

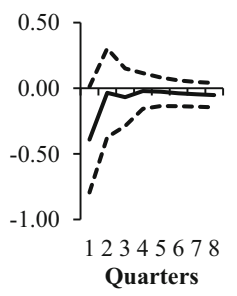

(l) Exchange rate

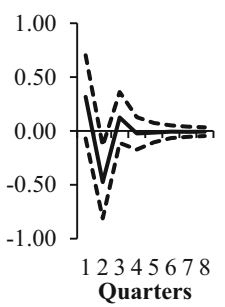

Fig. 4 Effect of shocks to pull factors on the components of the PI. 90\% confidence intervals. Sample: 1996 Q02-2015 Q04 (percent). Note: The variables used in the VAR model are: the VIX index, the growth rate of U.S. M1, the growth rate of U.S. GDP, the FFR, the growth rate of Mexican GDP, the interbank interest rate, the Mexican inflation, the growth rate of exchange (FIX) and capital flows

factors are dominant and, particularly, the role of the foreign interest rate has become more important with respect to other factors.

The response of PI to pull factors is shown in Fig. 4. Notably, a one standard deviation shock in Mexican GDP growth raises net PI by 0.59 in the same period of the shock, which may be associated with stronger economic fundamentals. Nevertheless, the shock to GDP has no significant effects on domestic and foreign investors' PI. The results for net PI indicate that an increase in economic activity is associated with larger inflows, which is in accordance with the pull factors literature and De Vita and Kyaw (2008), who highlight the importance of real variables to explain capital flows.

The effects on net PI flow of a one standard deviation shock to the Mexican overnight rate and the domestic inflation are not significant. Similarly, the response of PI by 
domestic investors is not statistically significant. That is, domestic investors seem not to change their investment in foreign securities when the real return on domestic assets changes. However, as it will be shown in the next section, real returns have effects on some of the components of PI.

A depreciation of one standard deviation in the exchange rate is associated with a decrease of 0.50 in the net PI, during the period after the shock occurs. Similarly, a depreciation causes a decline in domestic investors' PI of 0.48 in the second quarter. That is, domestic investors increase their holdings of foreign assets, which could be associated with higher returns in terms of domestic currency due to the appreciation of the foreign currency. The effect of the same shock on foreign investors' PI is not significant.

In summary, it appears that both push and pull factors are important determinants of net PI. Our results highlight the positive impact of Mexico's GDP growth on this type of investment. An increase in the U.S. interest rate has a negative and persistent effect on net PI and foreign investors' PI. Moreover, a positive shock to U.S. GDP growth has important effects on domestic investors' PI. We observe that the effect of a shock to liquidity and global risk on net PI is considerably important. Global liquidity rises the net PI (particularly foreign investors' PI), while higher global risk has negative effects on PI, which is consistent with a scenario of seeking refuge in what the investors consider safer assets.

Next, we show the response of OI to push factors in Fig. 5. As can be seen, a one standard deviation shock in the VIX is related to a 0.68 increase in total OI one quarter after the shock occurs. In this sense, OI by domestic investors shows a contemporaneous positive response $(0.73)$ to the shock in global uncertainty. That is, higher risk is followed by lower investment in foreign securities by domestic investors (as they tend to be risk averse). The same shock has no significant effects on OI by foreign investors.

The responses of OI and its components to a one standard deviation shock in liquidity and the FFR are not statistically significant. Thus, as the U.S. interest rates are more associated with the returns for PI than OI, the latter category seems to be less affected by U.S. interest rate shocks. However, we will show in the next subsection that some of the components of OI present a significant response. Finally, a shock in U.S. GDP growth is associated with a positive effect on net OI of 0.48 . This result may be explained by an income effect associated with higher U.S. GDP.

Figure 6 depicts the response of OI to pull factors. On the one hand, net OI flows respond positively to an increase in Mexican interbank interest rate at the first period (0.72), which can be explained by higher returns on these securities. On the other hand, higher domestic inflation is associated with lower real returns, which in turn creates less incentive to invest in Mexican securities. In fact, we find that a shock to domestic inflation is followed by a decrease of 0.52 on net $\mathrm{OI}$ and a diminution of 0.63 in foreign investors in the same period of shock. That is, we observe that the response of net OI flows is driven by foreign investor's movements. Net OI flows decline by 0.40 due to a depreciation of the exchange rate in the same period of the shock and by 0.26 in the third quarter. However, an exchange rate shock has no significant effects on foreign and domestic investment in OI. As can be seen, shocks to domestic conditions seem not to have significant effects on OI by domestic investors. That is, investment 
Response of OI

(a) Global risk level (proxy VIX)

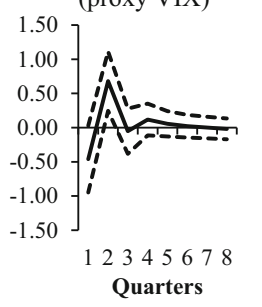

(e) Global risk level

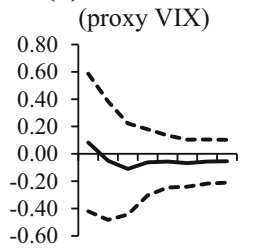

12345678 Quarters

(i) Global risk level (proxy VIX)

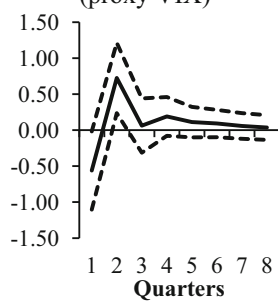

(b) Global liquidity (proxy M1)

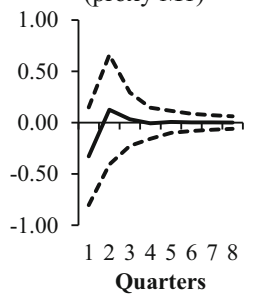

(c) U.S. GDP

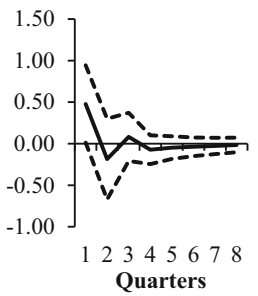

Quarters (d) U.S. Interest rate

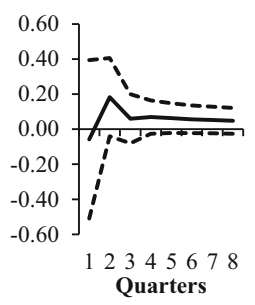

Response of OI by foreign investors

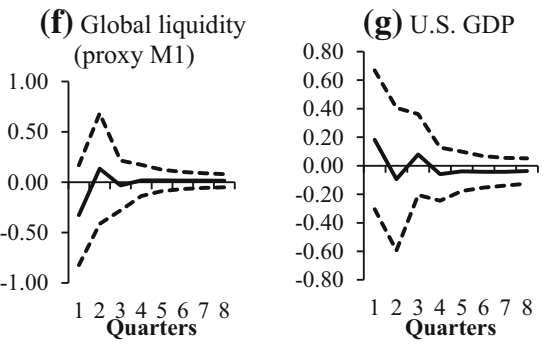

(h) U.S. Interest rate

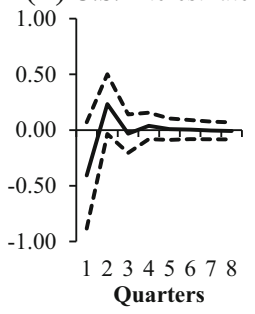

Response of OI by domestic investors

(j) Global liquidity

(k) U.S. GDP (proxy M1)
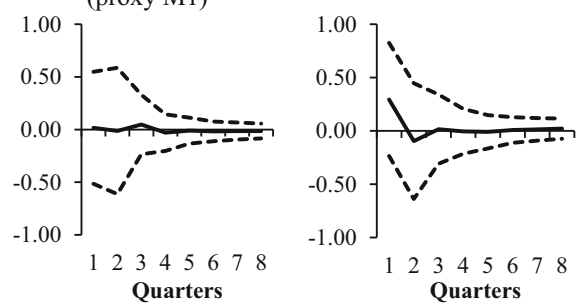

(l) U.S. Interest rate

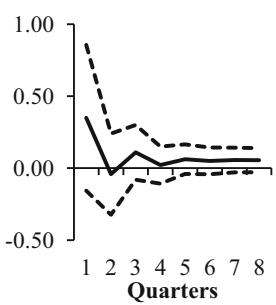

Fig. 5 Effect of shocks to push factors on the components of OI. 90\% confidence intervals. Sample: 1996 Q02-2015 Q04 (percent). Note: The variables used in the VAR model are: the VIX index, the growth rate of U.S. M1, the growth rate of U.S. GDP, the FFR, the growth rate of Mexican GDP, the interbank interest rate, the Mexican inflation, the growth rate of exchange (FIX) and capital flows

in foreign securities such as bank loans by domestic agents seems to be driven mainly by foreign conditions such as global risk.

Figure 7 shows the responses of net FDI to push factors. As can be seen, the responses of net FDI to shocks in the global risk, global liquidity, U.S. GDP growth and the U.S. interest rate are not significant. Finally, Fig. 8 presents the impulse-response functions to depict the effects of pull factors on net FDI. Although the negative effect of domestic GDP shock on FDI seems counterintuitive, the magnitude of the response is small (and marginally significant) compared to the positive response of PI. ${ }^{19}$ The

19 As capital flows are expressed as percentage of GDP, the domestic GDP shock could be reflected in a lower ratio of capital flows to GDP. However, in a robustness exercise, in which we express capital flows in logs, the effect of domestic GDP on FDI becomes not significant. 
(a) Mexican GDP

(b) Mexican interbank

Response of OI

(a) Mexican GDP interest rate
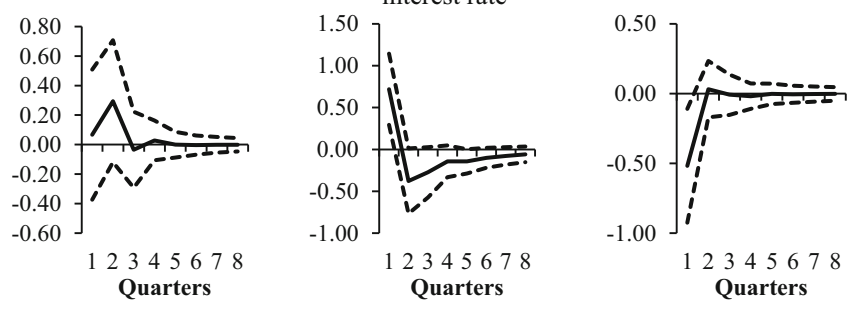

(d) Exchange rate

(e) Mexican GDP

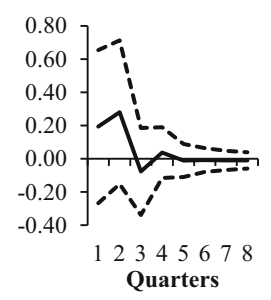

(i) Mexican GDP

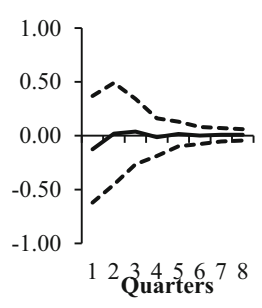

(f) Mexican interbank interest rate

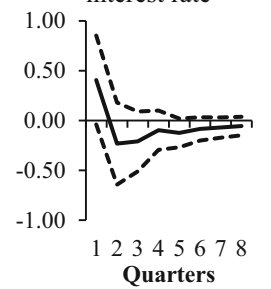

(g) Inflation

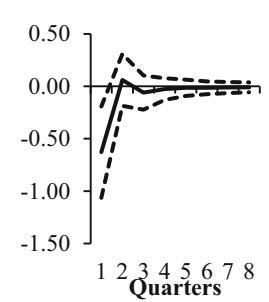

(h) Exchange rate

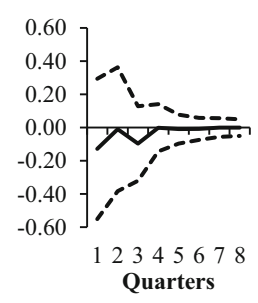

(j) Mexican interbank

estic investors interest rate

(l) Exchange rate
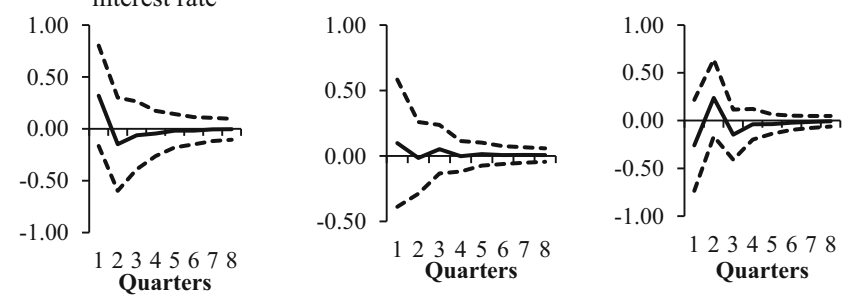

Fig. 6 Effect of shocks to pull factors on the components of OI. $90 \%$ confidence intervals. Sample: 1996 Q2-2015 Q04 (percent). Note: The variables used in the VAR model are: the VIX index, the growth rate of U.S. M1, the growth rate of U.S. GDP, the FFR, the growth rate of Mexican GDP, the interbank interest rate, the Mexican Inflation, the growth rate of exchange (FIX) and capital flows

exchange rate shock increases net FDI flows by 0.12 on the third quarter. This could occur if exports increase after the depreciation, thus making attractive the entry of FDI by exporting companies. In general, FDI does not seem to respond to short-term shocks as it is possibly determined by long-term economic fundamentals. These in turn are not captured in the VAR model as this framework is primarily useful for short-term analysis. That is, because FDI decisions tend to be long term, they may be based on additional information that is not included in our model. In summary, the impulse-response functions above show that push factors seem to have more important effects on PI and OI than on FDI. 

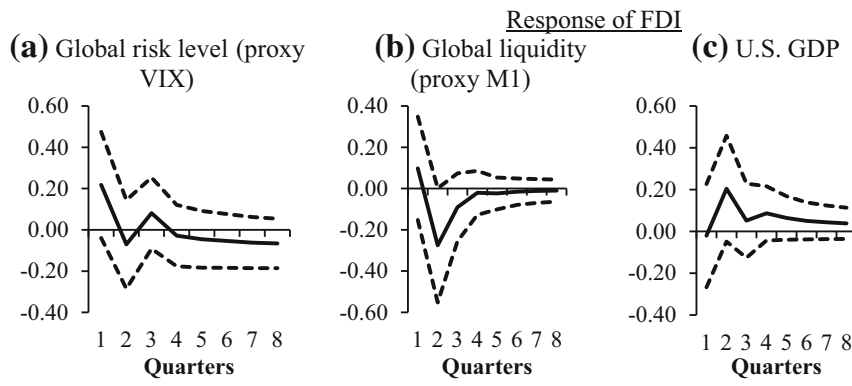

(d) U.S. Interest rate

(e) Global risk level (proxy VIX)

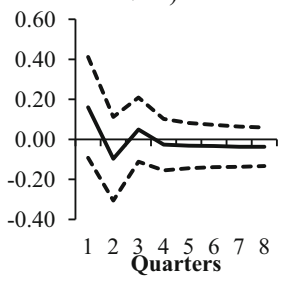

(f) Global liquidity
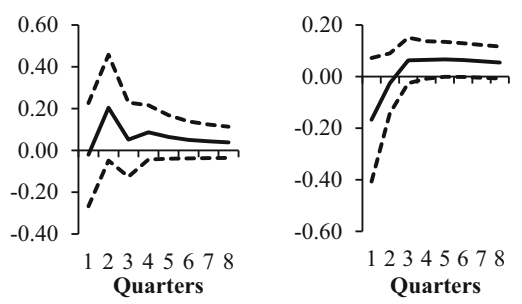

(h) U.S. Interest rate

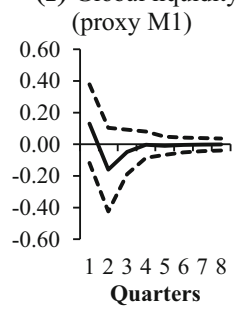

(g) U.S. GDP

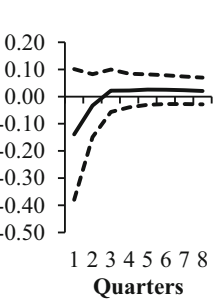

(i) Global risk level (proxy
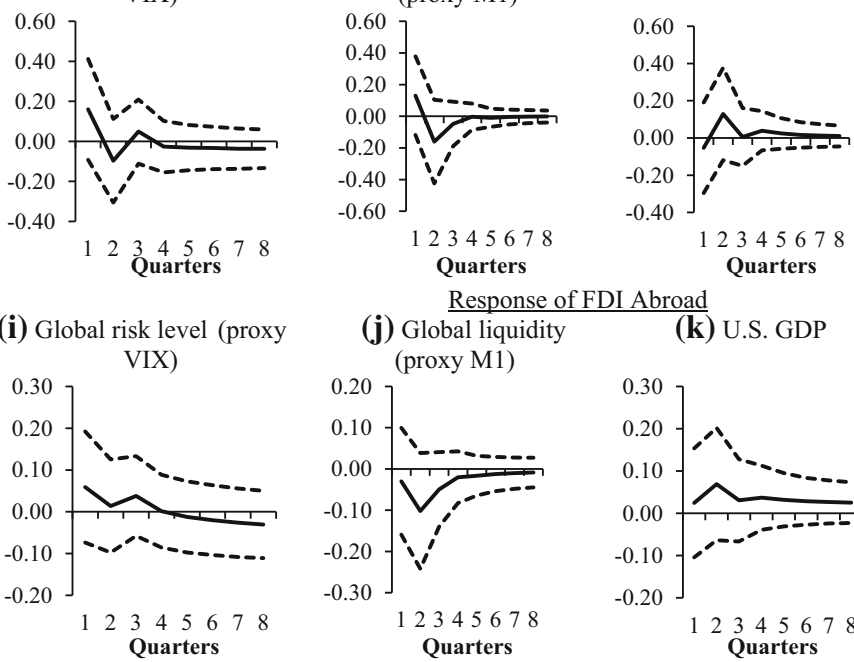

(I) U.S. Interest rate

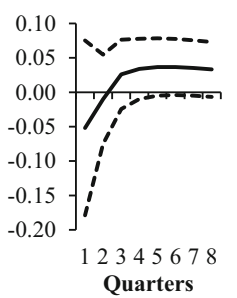

Fig. 7 Effect of shocks to push factors on the components of FDI. 90\% confidence intervals. Sample: 1996 Q02-2015 Q04 (percent). Note: The variables used in the VAR model are: the VIX index, the growth rate of U.S. M1, the growth rate of U.S. GDP, the FFR, the growth rate of Mexican GDP, the interbank interest rate, the Mexican inflation, the growth rate of exchange (FIX) and capital flows

\subsection{Robustness exercises}

For robustness, we also analyse other push and pull factors that affect capital flows. All of the results of the robustness exercises presented in this subsection are available from the authors upon request. A limitation of VAR models is that adding more variables implies a large number of parameters to estimate, resulting in a loss of degrees of freedom and leading to inefficient estimates. For this reason, our benchmark model includes only those variables that are more relevant to explain capital flows. However, we have considered alternative models that include other variables that could also be important. In particular, we include the Emerging Markets Bond Index (EMBI) ${ }^{20}$ for

\footnotetext{
20 The EMBI is measured as the difference between the interest rates of government bonds issued by emerging market countries and those issued by the U.S.
} 
(a) Mexican GDP

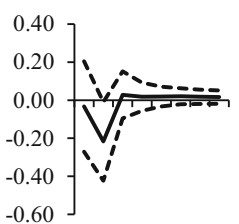

12345678 Quarters

(e) Mexican GDP

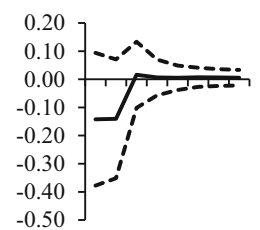

12345678

Quarters

(i) Mexican GDP

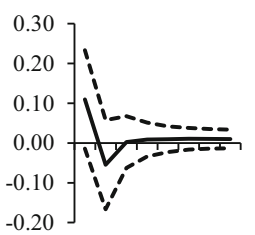

12345678

Quarters (b) Mexican interbank interest rate

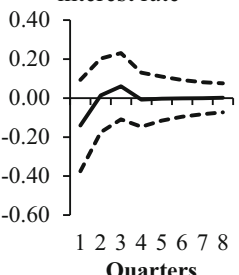

Response of FDI in Mexico

(f) Mexican interbank interest rate

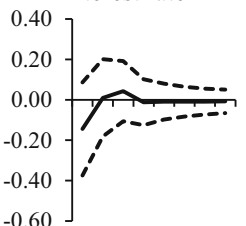

12345678

Quarters

Response

(j) Mexican interbank interest rate

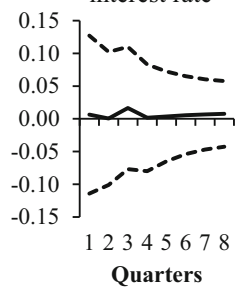

(c) Inflation

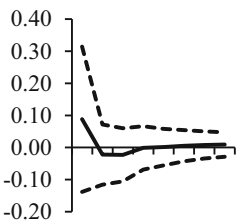

12345678 Quarters

(d) Exchange rate

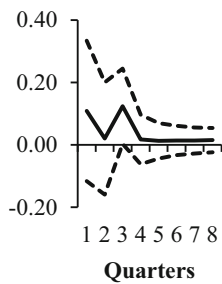

(h) Exchange rate

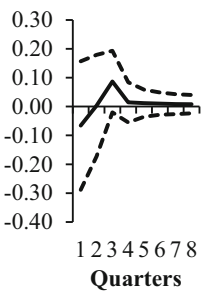

(l) Exchange rate

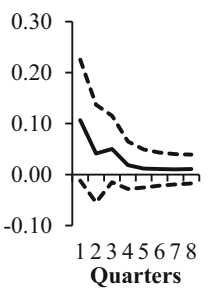

Fig. 8 Effect of shocks to pull factors on the components of FDI. 90\% confidence intervals. Sample: 1996 Q02-2015 Q04 (percent). Note: The variables used in the VAR model are: the VIX index, the growth rate of U.S. M1, the growth rate of U.S. GDP, the FFR, the growth rate of Mexican GDP, the interbank interest rate, the Mexican Inflation, the growth rate of exchange (FIX) and capital flows

Mexico and the Public Debt ${ }^{21}$ (as a percentage of GDP) as indicators of country-risk. Previous literature (e.g. Bohn and Tesar 1996) has found that this factor is an important determinant of capital flows. We find that, when the EMBI increases, OI by domestic investors shows a contemporaneous reduction. In addition, we find that higher public debt leads to higher portfolio investment in foreign securities by domestic investors. However, the shocks to the EMBI and the public debt have no significant effects on the other components of the financial account.

We also include in the model the implicit exchange rate volatility to account for future expectations about the exchange rate. In particular, we use the 1 month to maturity options for the peso-dollar exchange rate. We find that PI by foreign investors

\footnotetext{
${ }^{21}$ In particular, we use the total net debt of the public sector. This in turn includes the net debt of the Federal Government, public enterprises and official financial intermediaries (development banks and official trust funds).
} 
presents a contemporaneous reduction when the implicit volatility increases. However, this variable has no significant effects on other components of the financial account. A potential explanation is that this type of effect may already be captured by the exchange rate variable. In particular, shocks to the exchange rate volatility are typically associated with exchange rate depreciations, which in turn are already included in our baseline model.

In addition, we consider the interest rates in other Latin American countries to control for returns in emerging economies that could represent alternatives for foreign investors. In particular, we include a weighted average of the interest rates for Argentina, Brazil, Colombia and Chile, as well as the interest rates for Brazil's treasury certificates. ${ }^{22}$ The results show that, in both cases, the responses of FDI, PI and OI are not significant. This suggests that capital flows to Mexico are mainly driven by global and domestic conditions rather than conditions in other emerging economies.

Additionally, to account for the unconventional monetary policy measures implemented by the Federal Reserve, we include the shadow interest rate by $\mathrm{Wu}$ and Xia (2016). Overall, we find that the responses to a shock to the shadow interest rate are qualitatively similar to those using the FFR reported by the Federal Reserve. Note that our baseline model includes M1 to account for shocks to global liquidity.

We also estimate the model using alternative indicators of global liquidity, since the US M1 was affected by the large-scale asset purchases by the Federal Reserve after the global financial crisis. In particular, we use the total credit to non-bank borrowers from the BIS (2018) global liquidity indicators database and the TED spread (following Fratzscher 2012). In general, the results are consistent with our baseline specification. That is, we find that an increase in global liquidity is followed by higher some categories of capital inflows, particularly for OI by foreign investors.

As previously mentioned, in our baseline results, capital flows are expressed as percentages of GDP. For robustness, we also estimate the model expressing capital flows in logs, so that the responses can be interpreted as percentage changes. ${ }^{23}$ Overall, we find that the main conclusions of the paper are preserved. In contrast to our baseline results, however, we find that shocks to foreign interest rates and foreign liquidity show significant effects not only on portfolio investment by foreign investors but also on domestic investors. Nevertheless, the responses of foreign investors are more persistent, which provides support to our conclusion that foreign investors respond to a higher extent to these shocks compared to domestic investors.

We have also estimated the model starting from 2001, when the central bank adopted an inflation targeting regime. During this period, inflation in Mexico has remained low and stable. In general, the responses of capital flows to the push and pull factors are consistent with our baseline results. However, the lower sample size leads to a higher estimation uncertainty and a lower number of statistically significant responses.

As an alternative identification assumption, we also estimate the model using longrun restrictions as in Blanchard and Quah (1989). In this way, the accumulated response

\footnotetext{
22 These Latin American countries have been analysed in previous literature on capital flows, including, for example, Chuhan et al. (1998) and Fernandez-Arias (1996).

23 To handle with negative values commonly found in capital flows data, we add a constant to the data prior to applying the log transformation. In particular, the constant is such that the minimum value of the series is one.
} 
of foreign variables to a shock on the domestic variables is zero in the long run. In particular, we use a diagonal response matrix as in the Cholesky method explained above, but using long-run instead of short-run restrictions. The results are similar to those presented in this paper. In the next section, we analyse the determinants of each component of the financial account at the highest degree of disaggregation, which allows us to obtain more details about the dynamics of disaggregated capital flows.

\subsection{Responses of disaggregated capital flows to push and pull factors}

In this subsection, we present the responses of all components of the financial account to shocks in push and pull factors. This is motivated by the findings of Forbes and Warnock (2012) and Broner et al. (2013) and because the different types of capital flows might be driven by different types of factors, according to their particular features. Table 1 provides a brief definition of each component of the financial account. The responses of disaggregated capital flows are shown in Tables 3, 4, 5, 6, 7, 8, 9 and 10. To preserve parsimony, the VAR models in this subsection include only one component of the financial account. That is, we estimate 22 models, one for each of those components. To facilitate the comparison, we present at the same time the responses of all items of the financial account to each particular shock.

The increase in global uncertainty is associated with a reduction in capital inflows in several components of the financial account, as expected since investors tend to be risk averse. The negative response of PI to the shock in global risk is due to the impact on both foreign and domestic investors' flows. Foreign investor's PI decrease by 0.81 p.p. of GDP at the first period, which is mainly explained by a decrease in the public sector securities of 0.42 and a diminution of 0.34 in private sector securities. Within the latter, securities issued abroad and securities of stock and money market present a reduction 0.19 and 0.17 , respectively, on the first quarter. The negative response of foreign investors' PI is almost offset by an increase of 0.71 in domestic investor' PI during the same period of shock. Notably, we observe that the holdings of public sector securities by foreign investors rise after the increase in global uncertainty, although with a lag. That is, foreign investors seem to prefer these types of investment when global uncertainty is higher as they have lower risk in comparison with private securities.

Similarly, many of the components of OI present a reduction following the rise in global uncertainty. In particular, a shock to the VIX index is followed by a decrease in the domestic investors' OI by $0.56 \mathrm{pp}$ of GDP in the same period of shock. Similarly, we observe a reduction in the non-banking private sector's accounts by foreign investors of 0.11 the second period after the shock. Remarkably, holdings of public sector securities by foreign investors, particularly in development banks, increase in an environment of high uncertainty, which possibly occurs due to the lower risk in these types of securities relative to private sector securities.

An increase in liquidity is followed by higher inflows for several components of the financial account, particularly for PI. This can occur because a relaxation of liquidity implies a larger amount of funds to invest. The injection in U.S. liquidity affects PI by foreign investors, but not for domestic investors. That is, as foreign investors are expected to be directly affected by the shock in U.S. liquidity, their response is larger than that of domestic investors. In particular, PI flows by foreign investors in the 


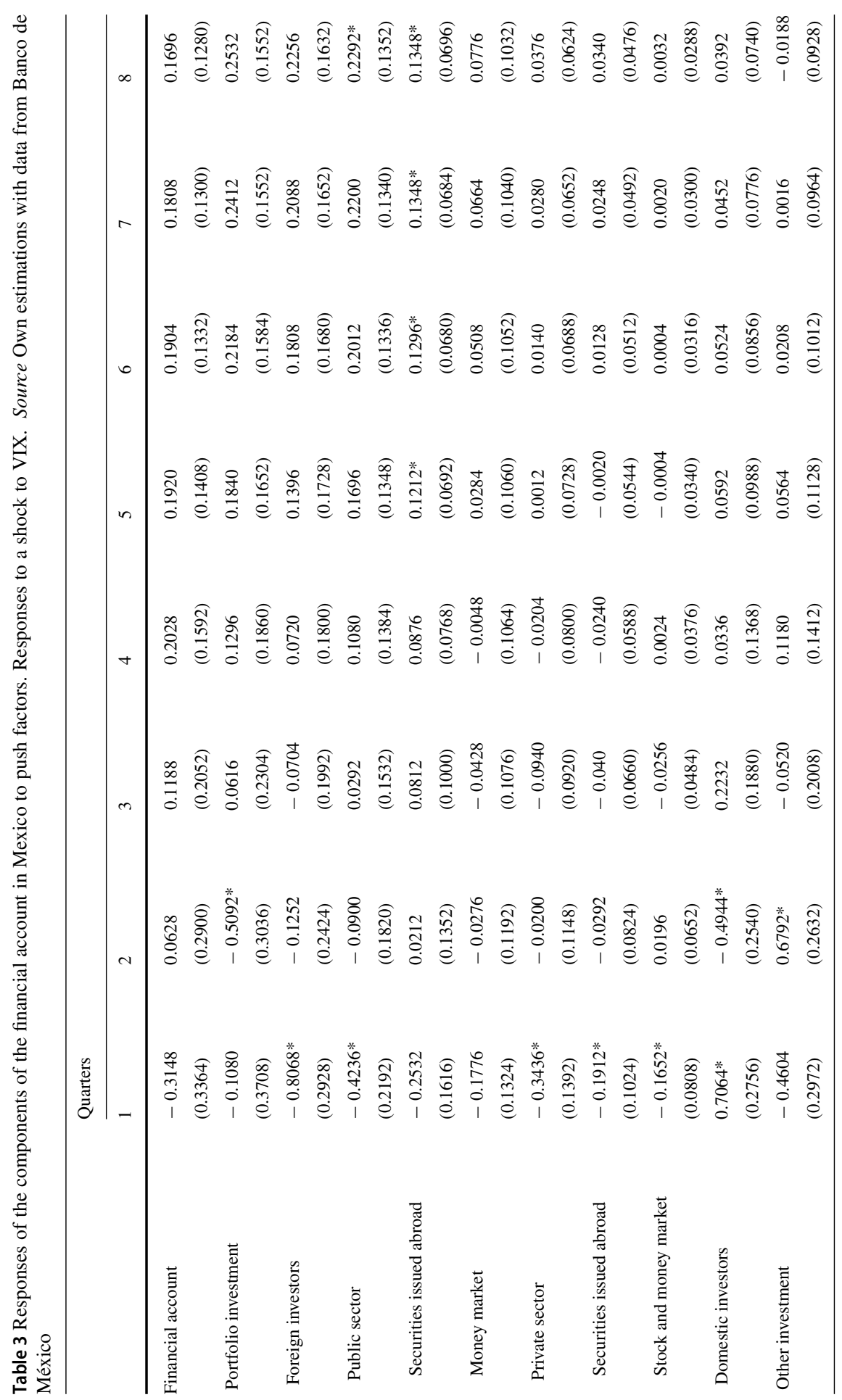




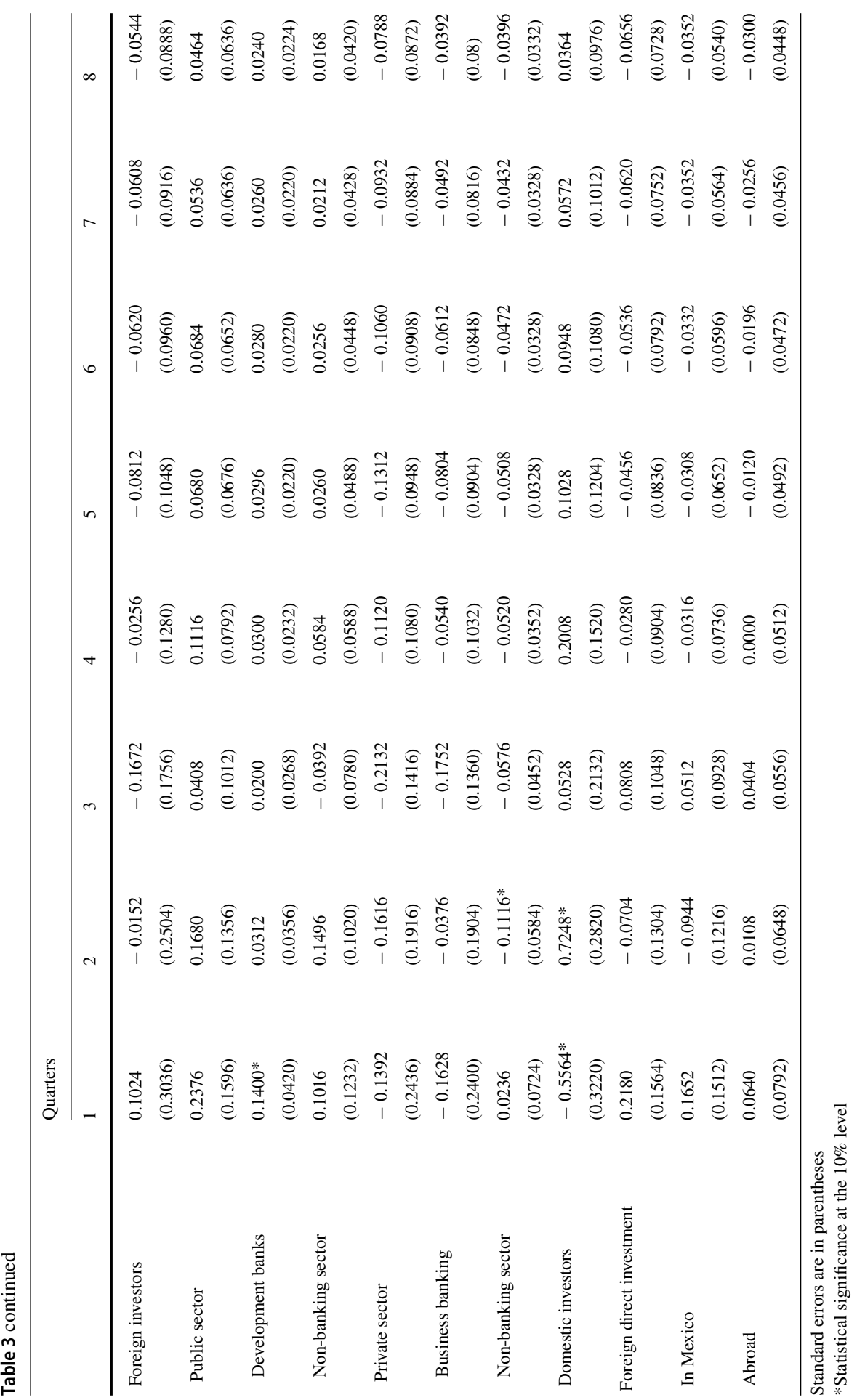




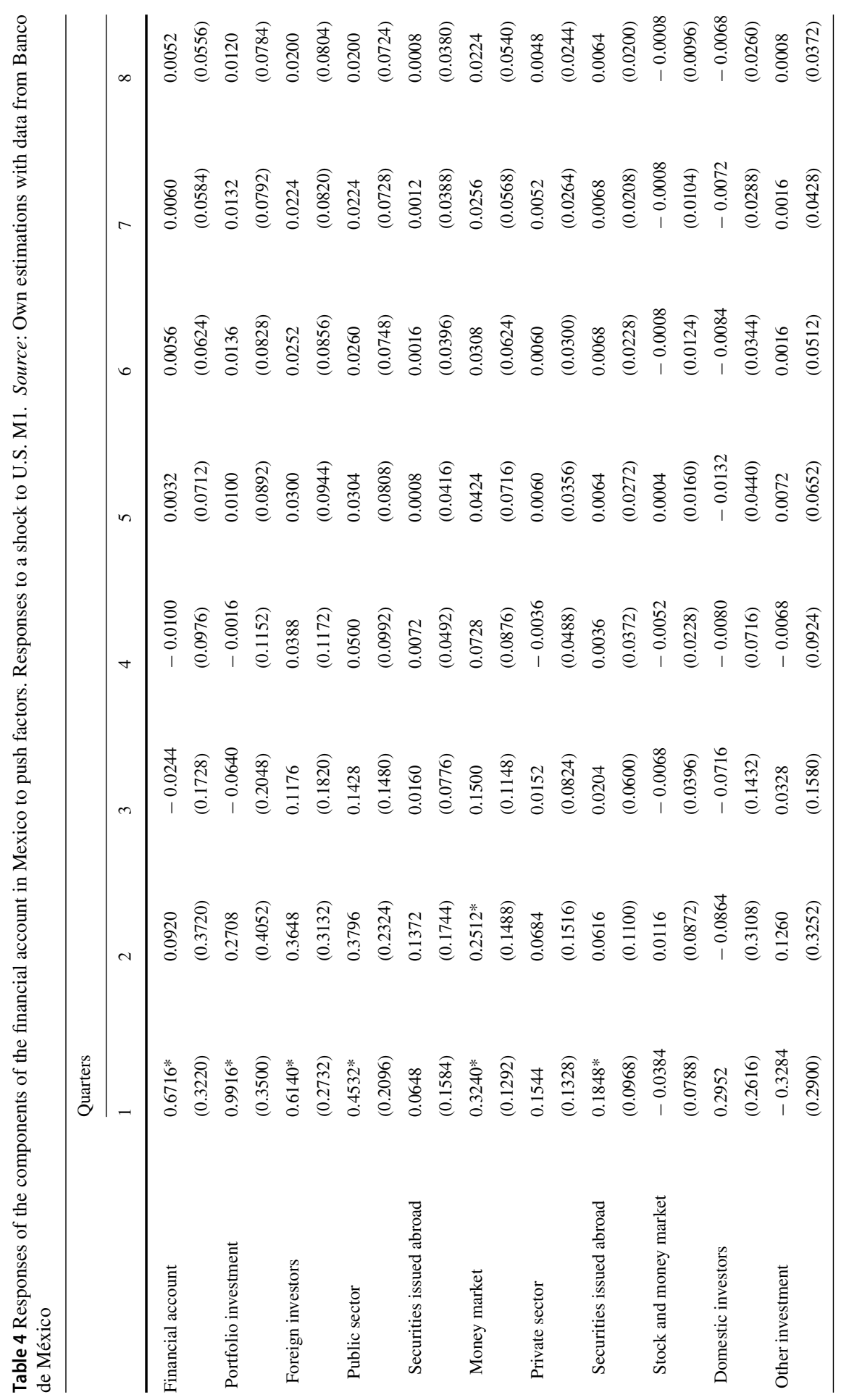




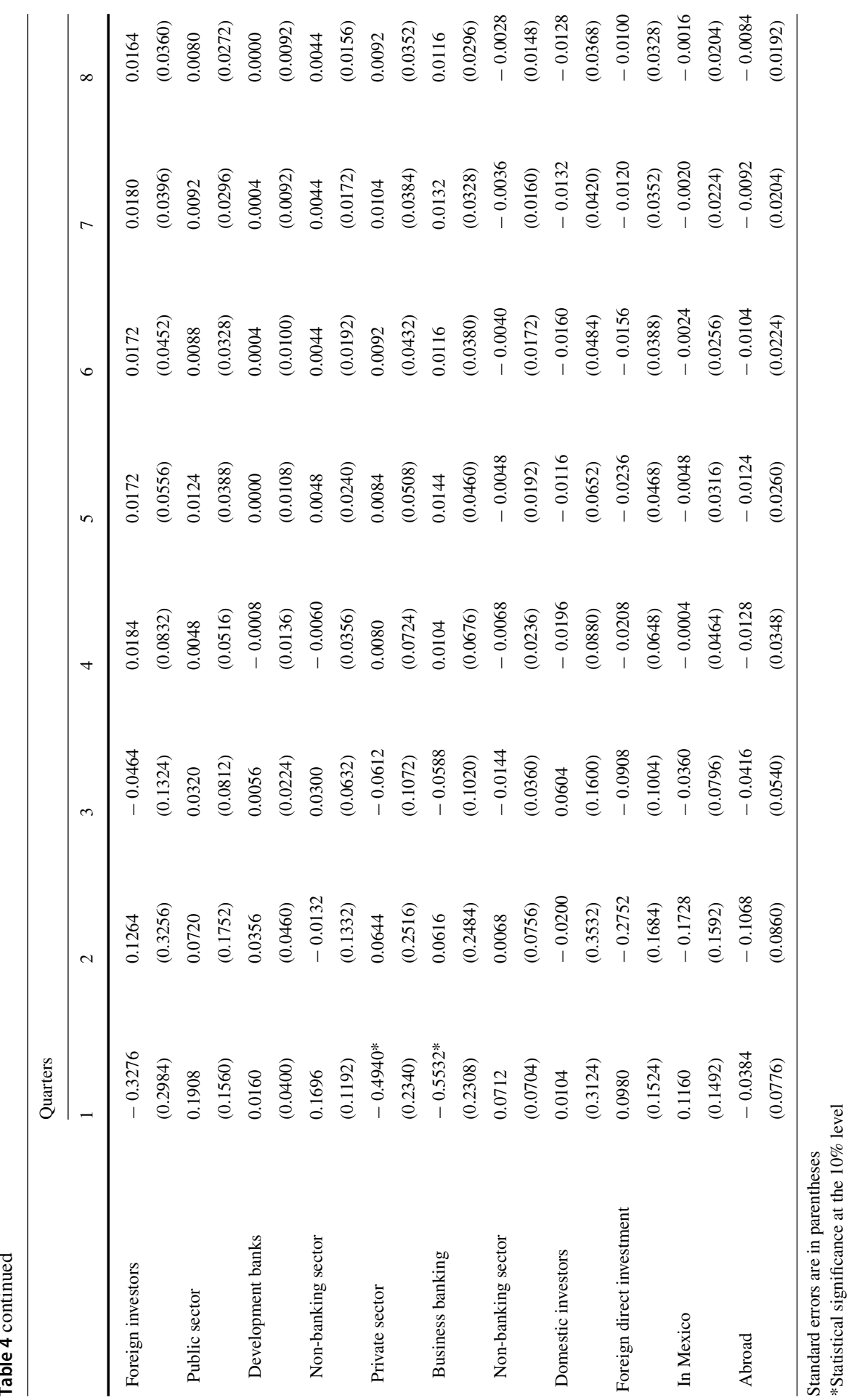




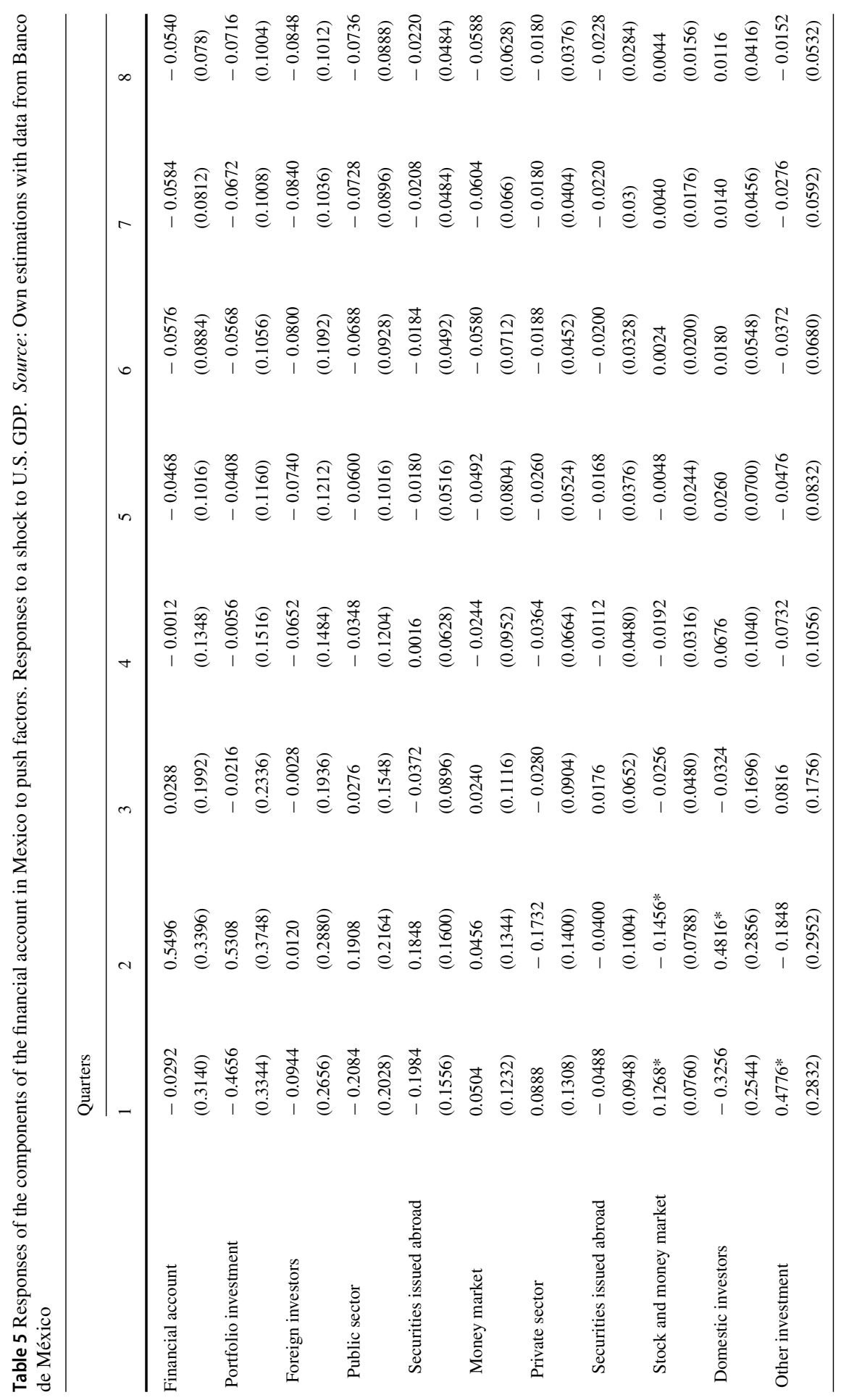




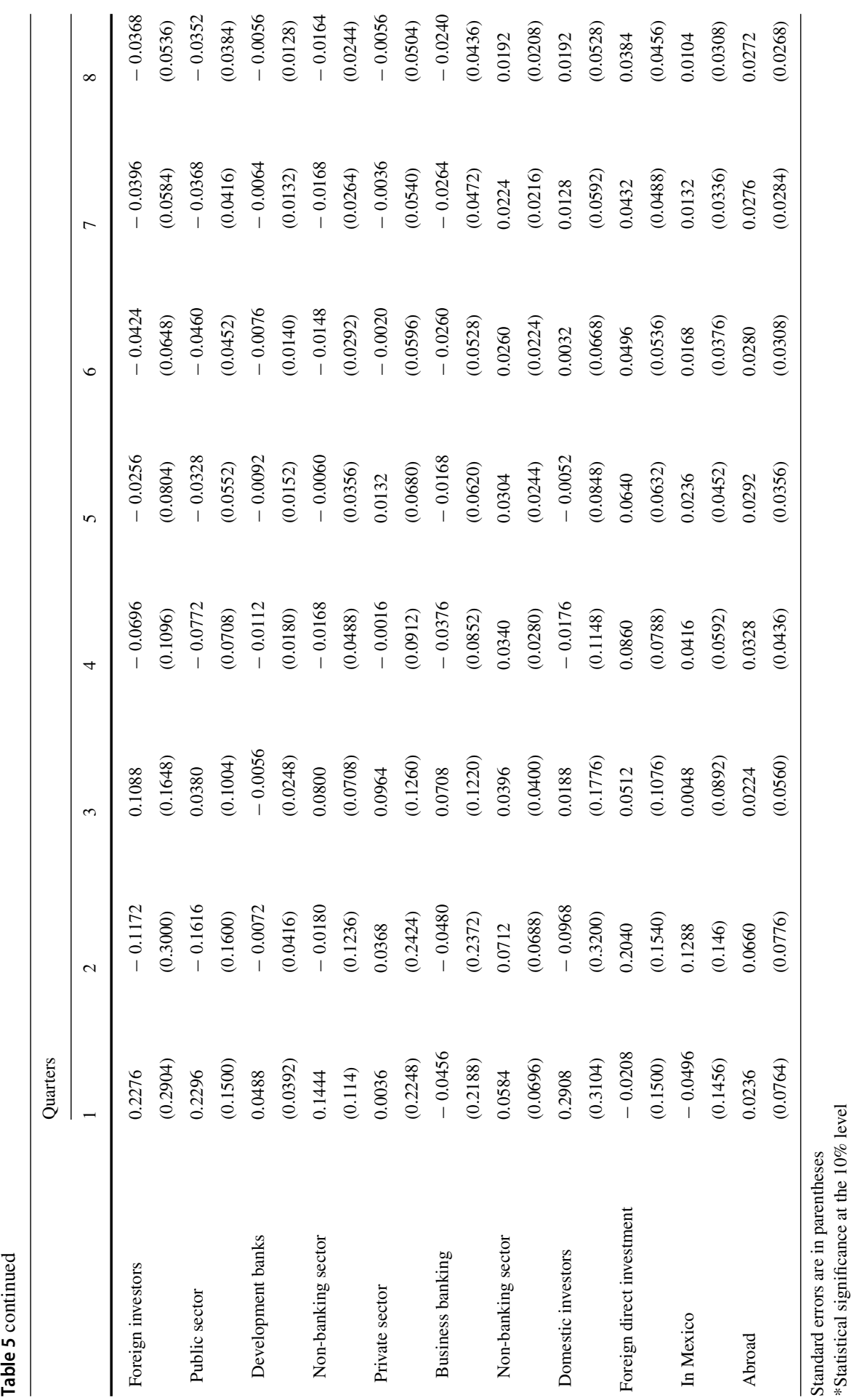




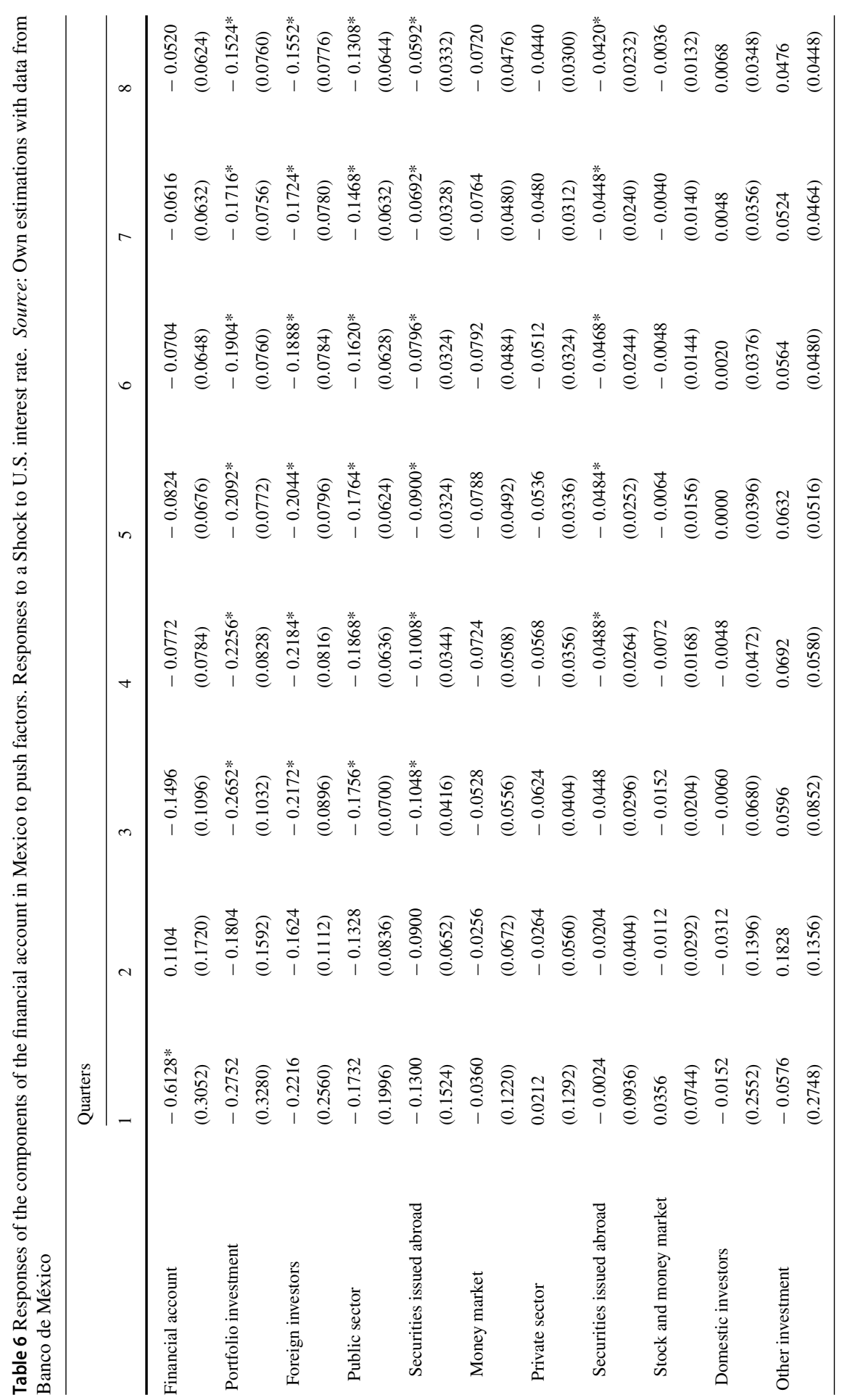




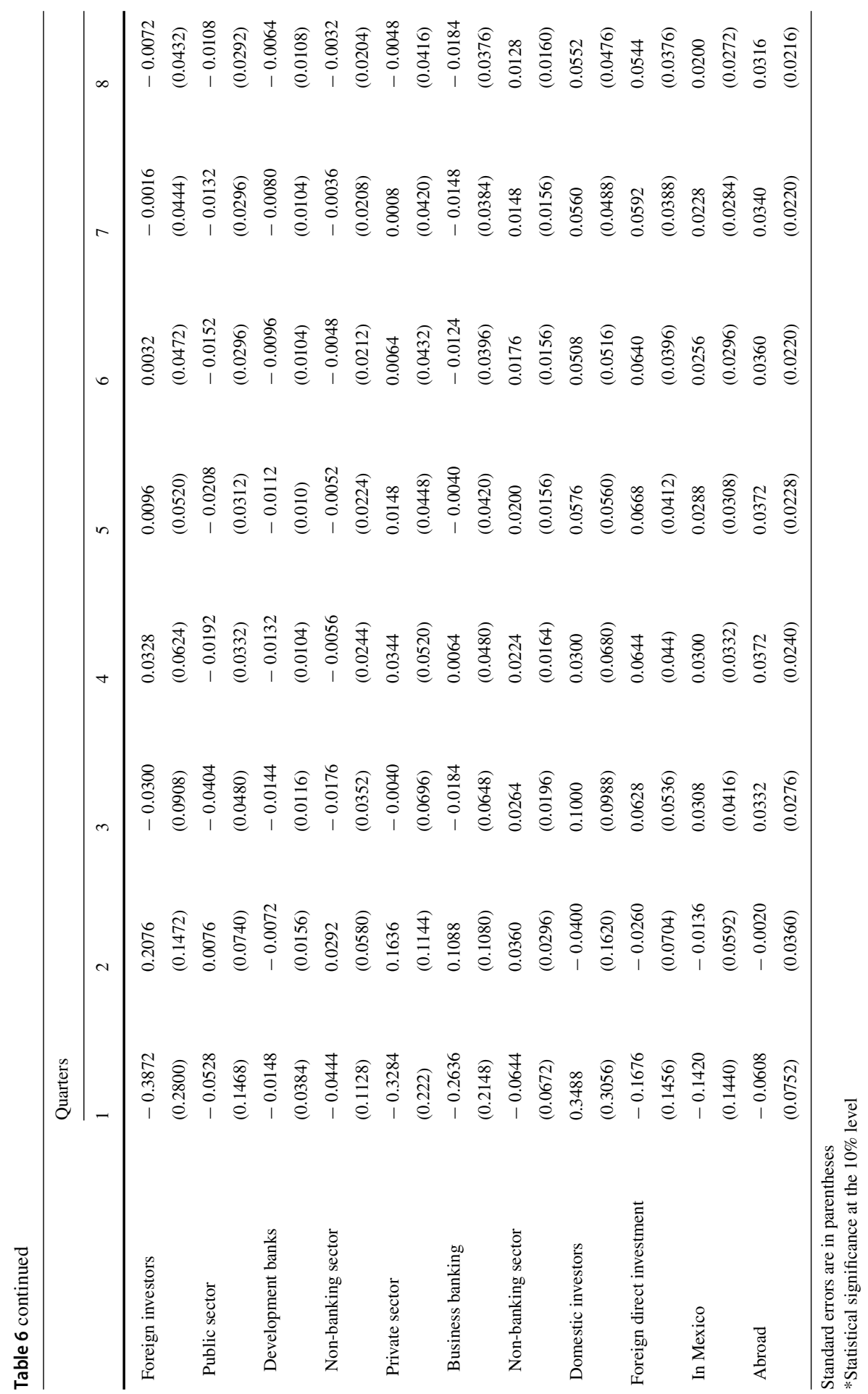




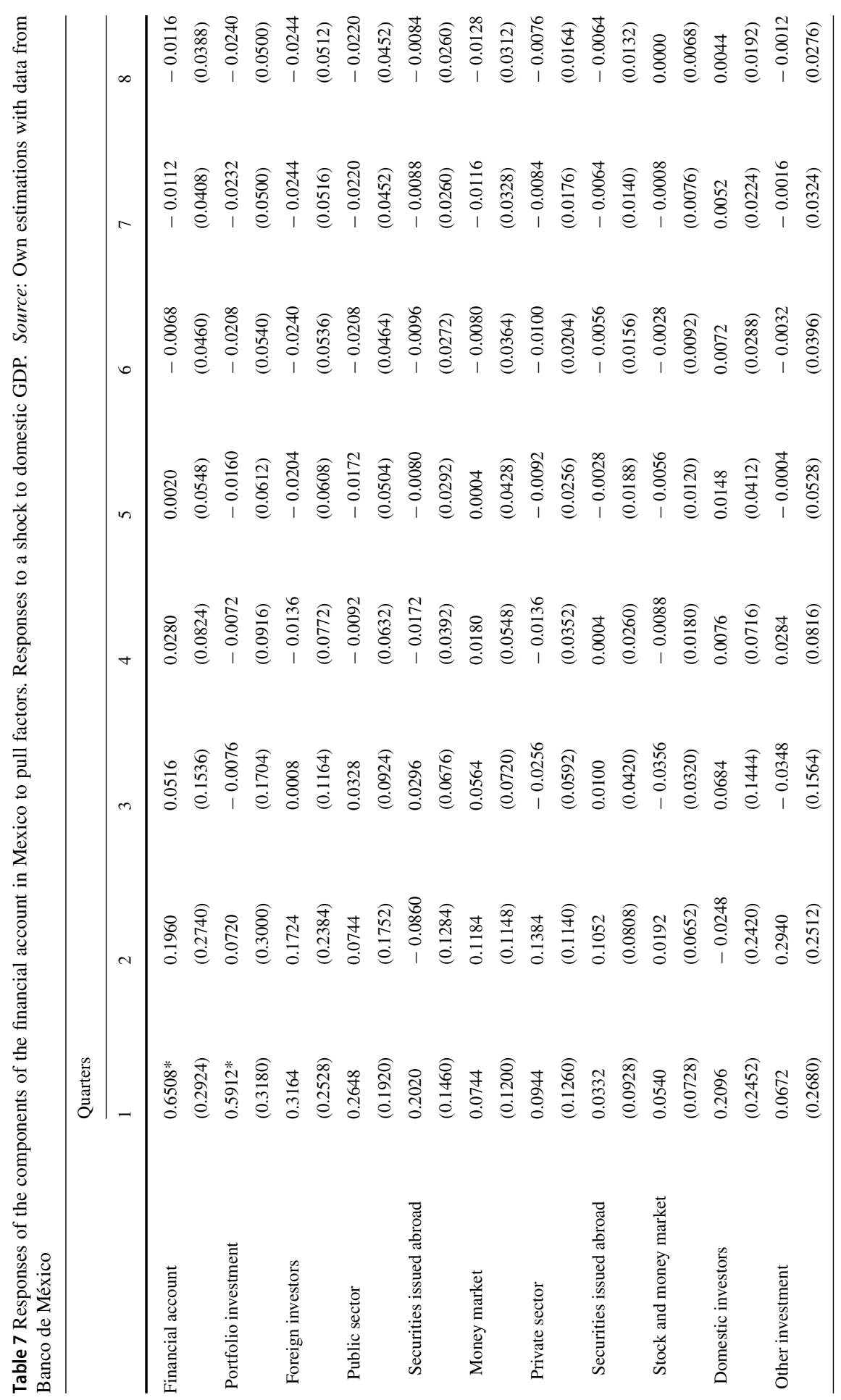




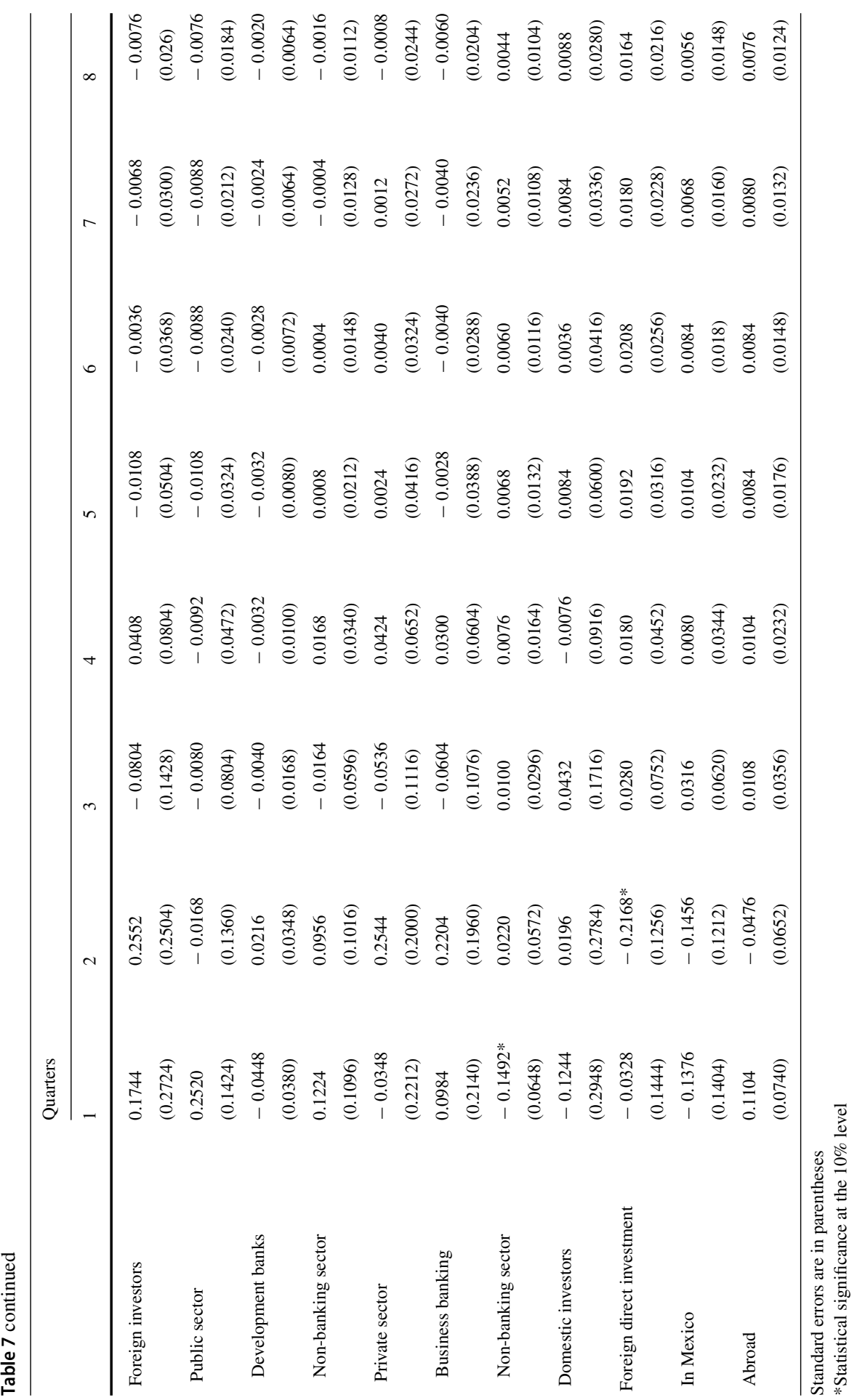




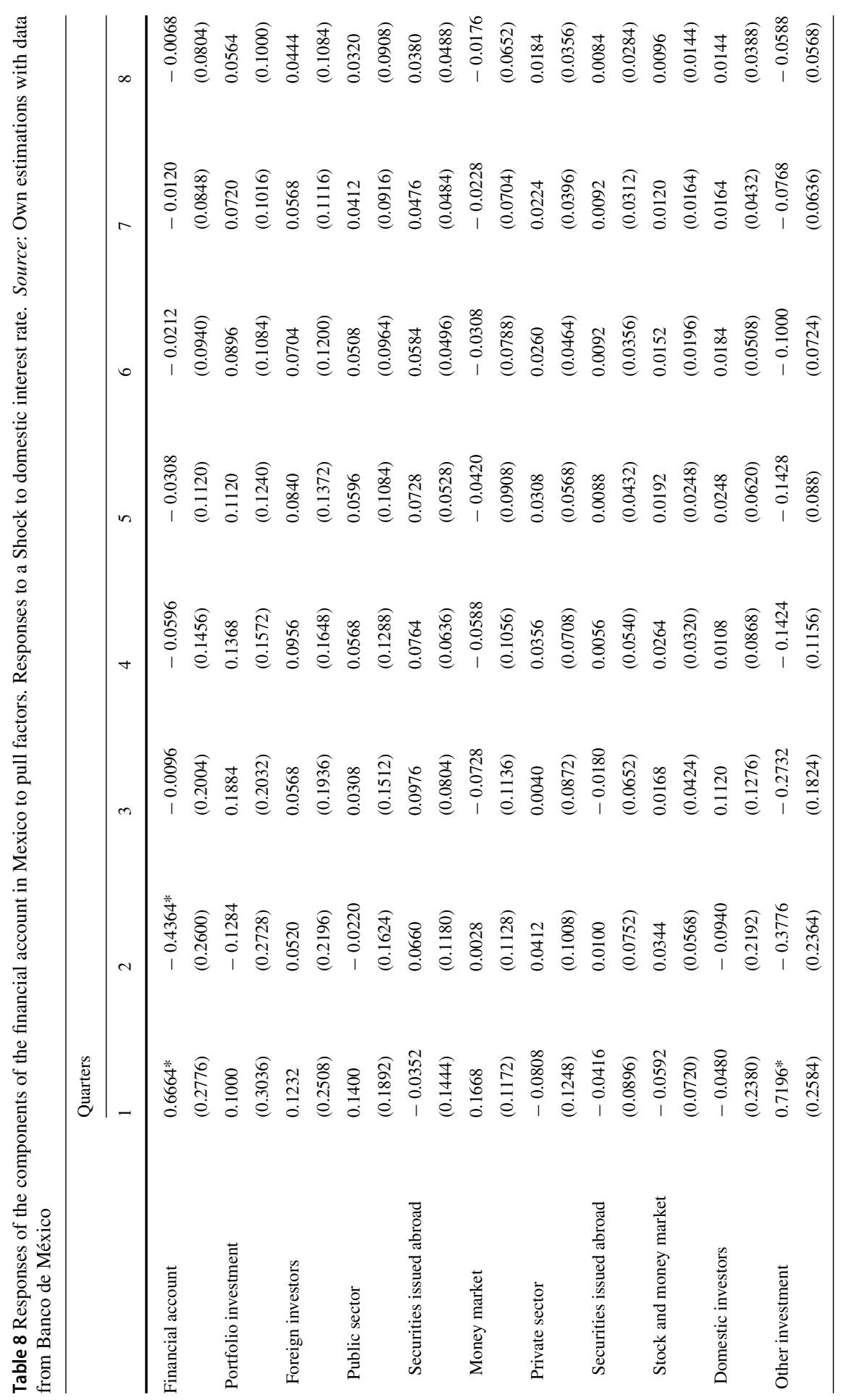




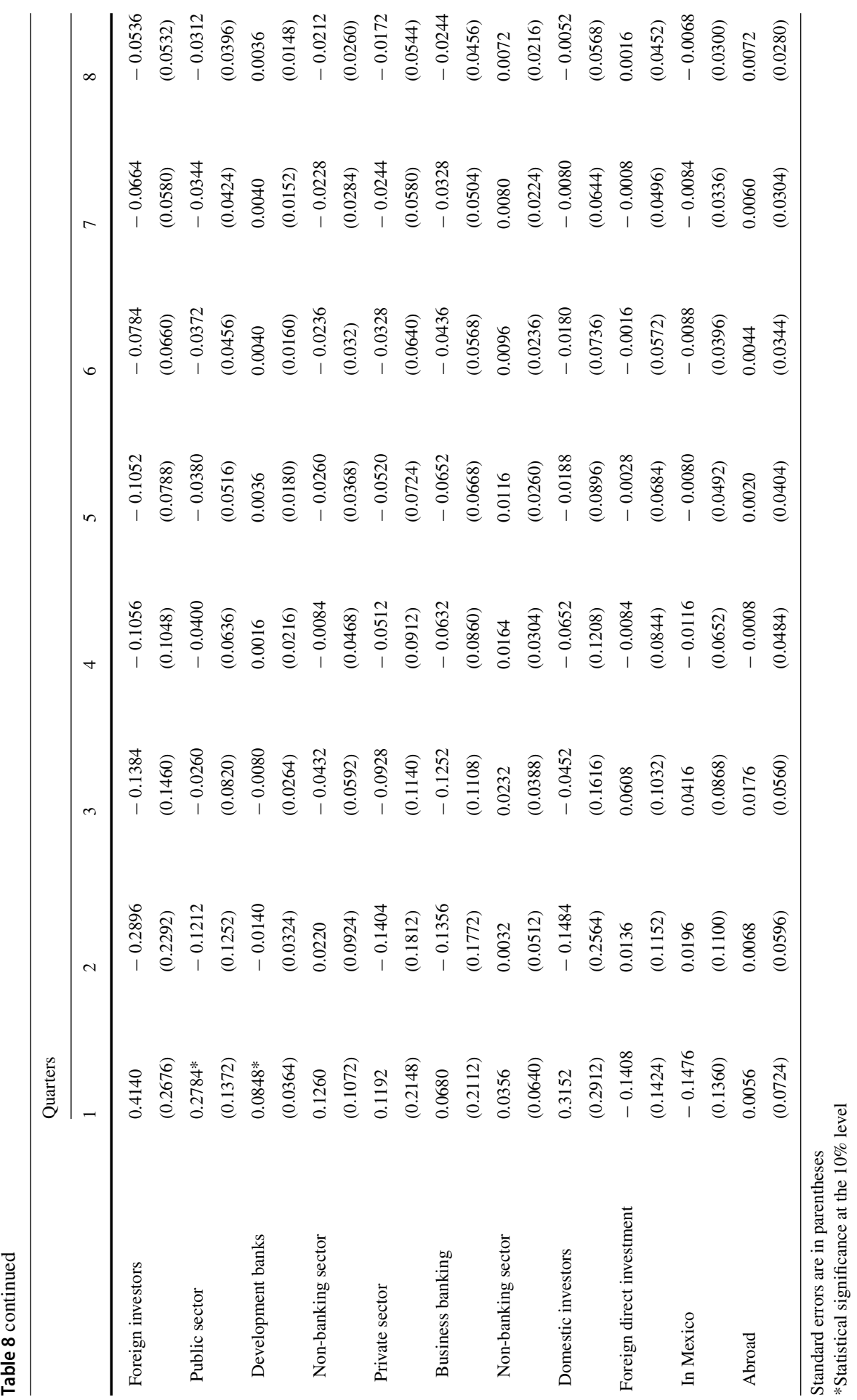




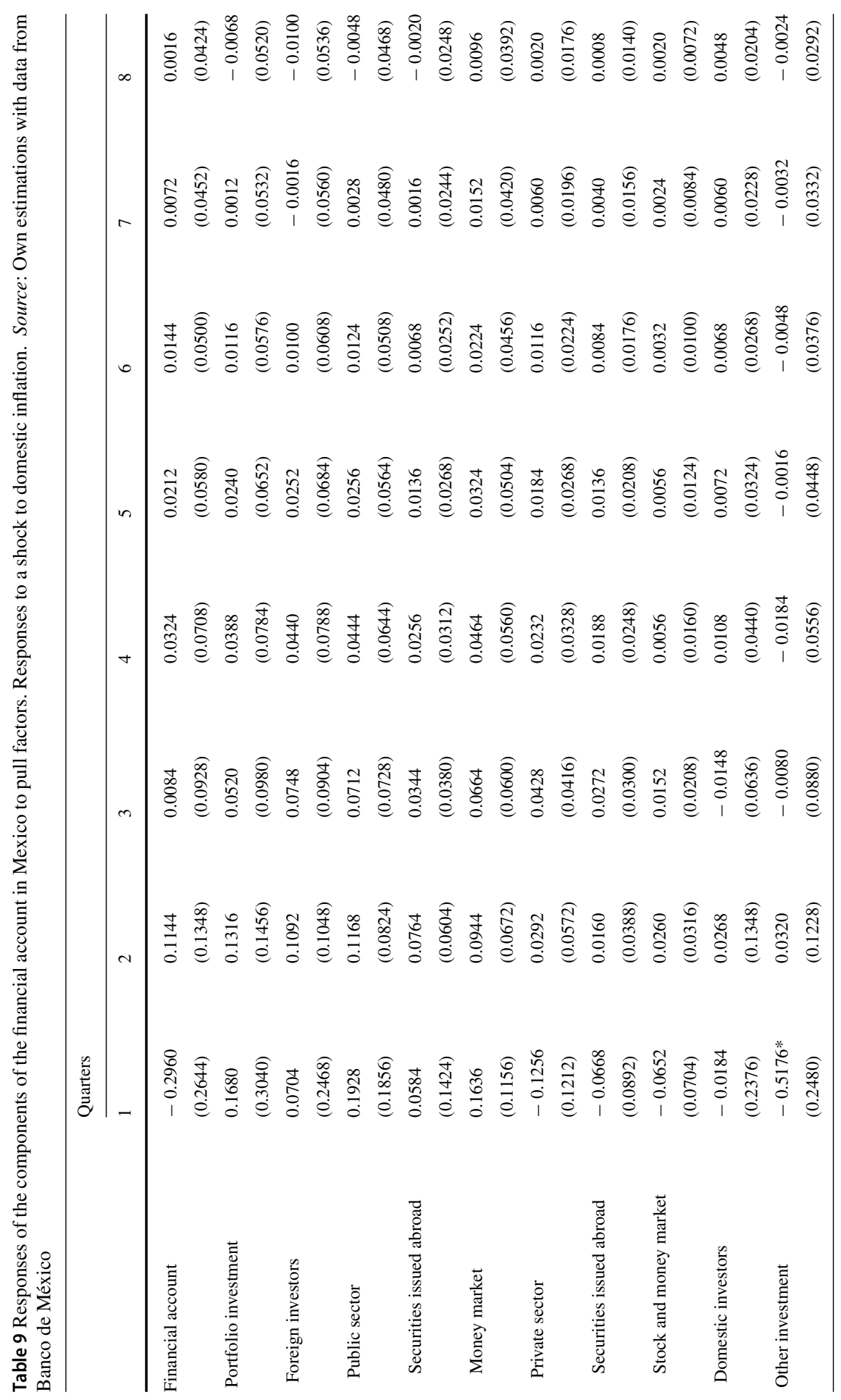




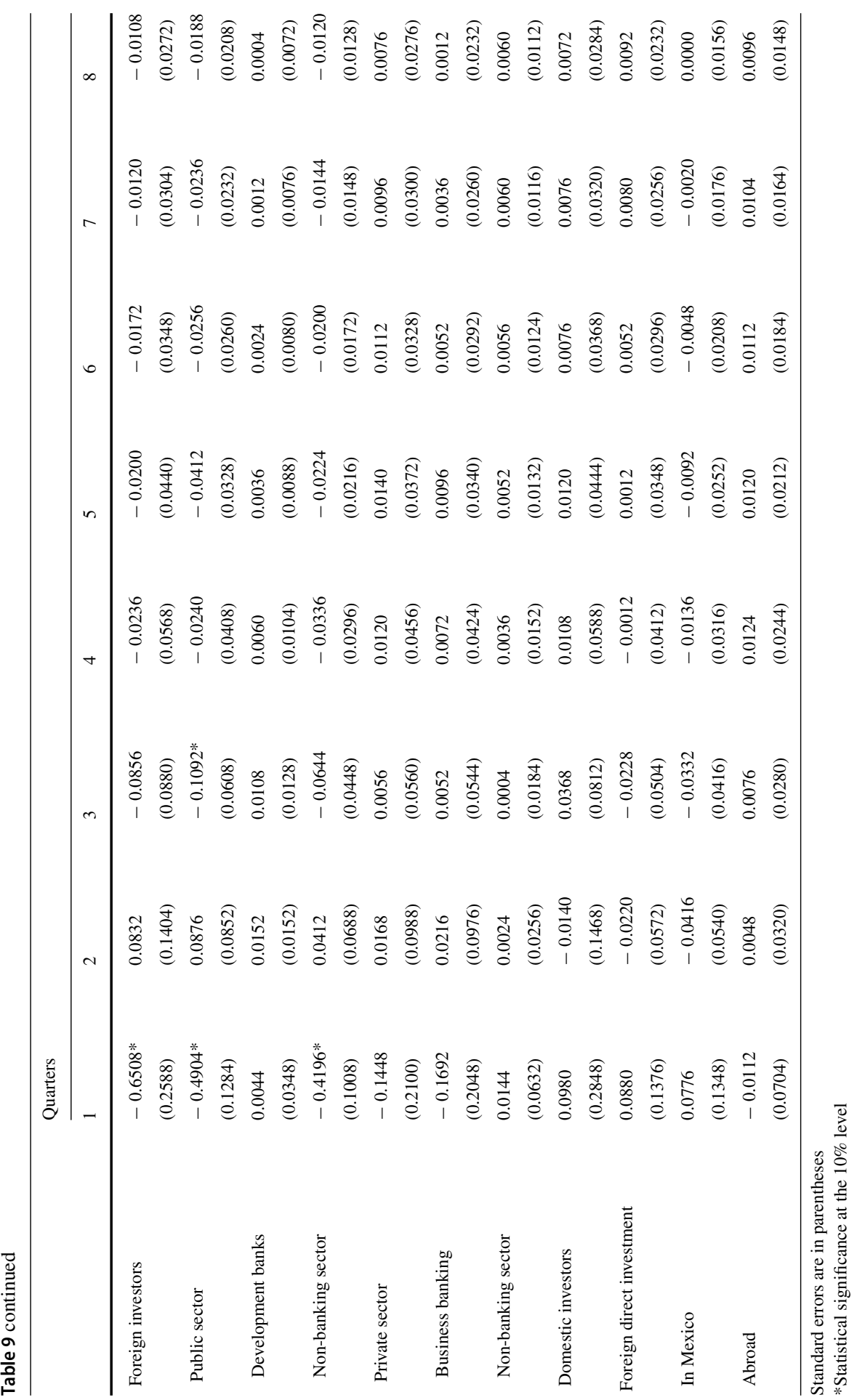




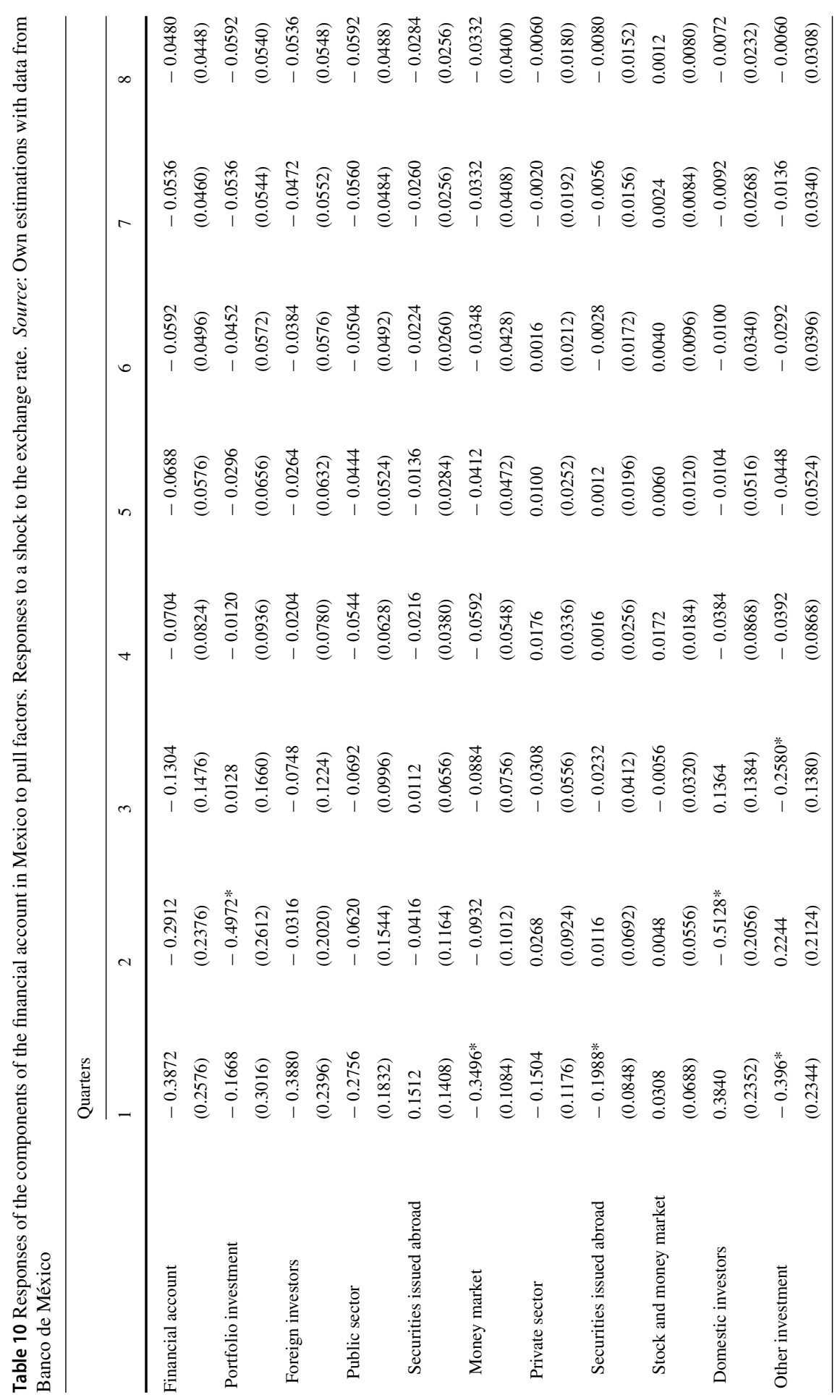




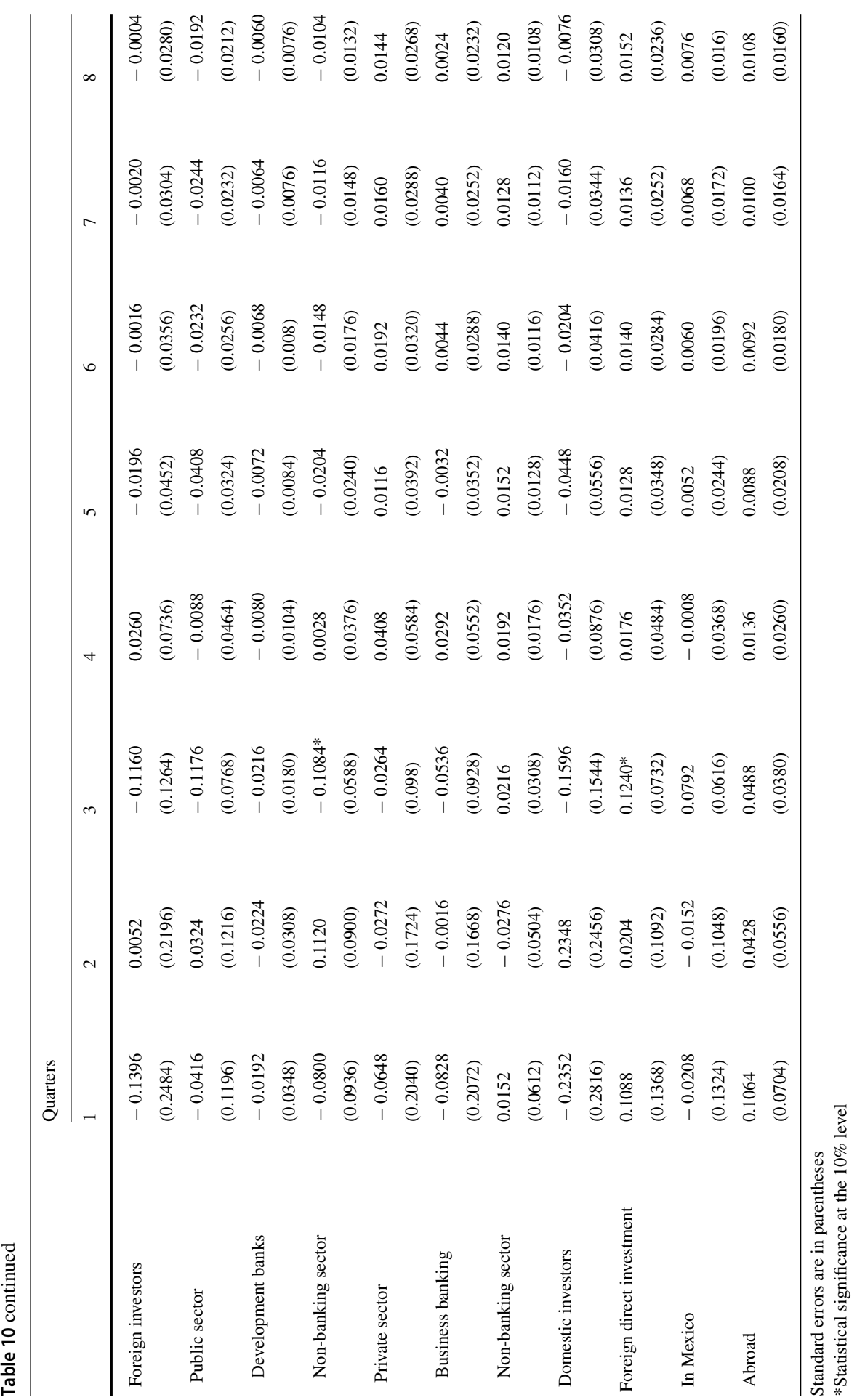


first period raise by 0.61 . Importantly, we observe that the flows for money market securities of the public sector respond positively to a liquidity shock during the first two periods, while securities issued abroad in the private sector rise by 0.18 on the first period. This supports the conclusion of Fratzscher (2012), who finds that a relaxation of liquidity conditions induces net portfolio inflows. The effects of U.S. M1 shocks on net OI, however, are not significant. Importantly, even if there are not significant responses in net OI flows, the disaggregation by components shows significant effects. In particular, we find that flows for foreign investors in private sector securities decrease by 0.49 , which in turn is driven by a negative response of the flows in Business Banking securities of 0.55 . This could occur if there are feedback effects between PI and OI.

A rise in the U.S. GDP growth is associated with a 0.48 increase in domestic investors' PI, one quarter after the shock. The same shock is associated with a rise of around 0.13 in stock and money market securities within the private sector by foreign investors at the first quarter and a decrease of 0.15 during the second period. The positive shock to U.S. GDP is followed by an increase in inflows in OI by 0.48 , which is possibly associated with a wealth effect from the increase in U.S. GDP.

An increase in the FFR represents higher returns abroad; thus, it leads to an important reduction in several components of PI by foreign investors. In particular, we can see persistent impacts from the third to the eighth periods, on net PI, which seems to be driven by a reduction in public sector securities by foreign investors. We also observe some negative effects on securities issued abroad in private sector, although smaller in magnitude. That is, changes in the FFR have an important negative effect on the demand of public sector's securities, which are close substitutes of U.S. government bonds. Interestingly, the effect of shocks in the FFR on the financial account is driven by the behaviour of foreign investors, as domestic investors do not seem to respond to the shock. These results give support to those found in Chuhan et al. (1998), who indicate that the effect of U.S. interest rates is more important than that of U.S. output. Moreover, these results are consistent with the results in Calvo et al. (1993), who found that in most cases, an increase in interest rates abroad induces a capital outflow (for example, in Argentina, Bolivia, Colombia, Chile, Mexico, Uruguay and Venezuela).

Next, we discuss the response of the flows to pull factors. A shock to Mexican GDP growth raises the financial account by $0.65 \mathrm{pp}$ of GDP. This result is expected as higher domestic economic activity generates incentives to invest in Mexico, as it is possibly associated with higher future returns. This effect is mainly driven by an increase in net PI by 0.59. We observe some negative responses in some items of the financial account that might be associated with a substitution effect from OI and FDI to PI. However, as they are small in magnitude, the net effect of higher GDP on the financial account is positive.

Regarding the shock to the domestic interest rate, we would expect larger capital flows associated with larger returns in domestic securities. We find that the impact of the Mexican overnight rate on the financial account is positive during the first period by 0.67 and negative the second period, although smaller in magnitude. This response is mainly driven by a positive impact in OI. In particular, we observe an important increase in holdings of public sector securities by foreign investors, which can occur as the return on these type of investment is highly related to domestic interest rates. 
The domestic inflation shock has only a negative effect on OI of 0.52 , as it is associated with lower real yields in domestic securities. This is explained by a diminution of 0.65 in foreign investors' flows during the same period of shock. This in turn occurs as a result of the dynamics presented in the public sector flows' OI (decreasing by about 0.49 ). The same shock produces a reduction of non-banking sector's flows of around 0.42 .

An exchange rate depreciation is associated with negative movements into PI and OI. This can occur due to lower expected yields in foreign currency. In particular, this shock decreases net PI flows by 0.50 at the second quarter. This response is driven by the behaviour of domestic investors' flows $(-0.51)$. That is, their investment in foreign assets increases, which could be associated with larger expected returns in domestic currency. Also, we observe a reduction in money market holdings within the public sector (0.35) and on securities issued abroad within the private sector (0.20) in the same period of the shock. The response of OI to that shock is negative during the first and third quarters, respectively. This response is explained by a reduction in the nonbanking sector's flows (0.11) at the third period. Also, the positive response of FDI's flows, by 0.12 at third period, suggests a substitution effect between capital flows. This could occur if exports increase after the depreciation, thus making attractive the entry of FDI by exporting companies. ${ }^{24}$

Finally, we discuss the net effects of the shocks on the financial account. The impulse-response functions are significant for the case of the level of global liquidity and the U.S. interest rate. In particular, a shock in the level of global liquidity has a positive response of 0.67 , while the effect of the FFR shock is negative (0.61). Pull factors have only statistically significant responses on the financial account for the cases of GDP growth and domestic interest rate. For a shock to the Mexican GDP growth, the effect on financial account is 0.65 in the first period. The response of the financial account to the domestic interest rate shock is 0.67 during the first period and -0.44 at the second period.

Previous literature about the determinants of capital flows can be used to assess the extent to which our results could be applicable to other economies. In particular, Fratzscher (2012) finds that the impact of common shocks (such as global liquidity and risk) on capital flows depends on a country's strength of domestic institutions, risk assessment and macroeconomic fundamentals. Similarly, Milesi-Ferretti and Tille (2011) show that the impact of shocks on a country's capital flows is associated with the size of its external liabilities, macroeconomic conditions (growth, credit and fiscal position) and its dependence on exports. Other papers have suggested that the effects of shocks on capital flows depend on regional factors. For instance, using a hierarchical factor model, Förster et al. (2014) find that the country-specific component explains the largest fraction of fluctuations in capital flows followed by regional factors, while

\footnotetext{
24 We exclude three categories of the financial account from the analysis, particularly those corresponding to Pidiregas in PI, Pidiregas in OI, and a category that includes securities issued by the Mexican Central Bank. Pidiregas refers to the "Productive Infrastructure Investment Project with Record Deferred in the Public Expenditure" which essentially entails a set of public projects financed by the private or social sectors. The Pidiregas categories have taken the value of zero since 2009, when those types of investments disappeared. Similarly, we observe zero flows in the Mexican Central Bank category since the second quarter of 2010. As those accounts take zero values for an important part of the sample, the estimation results could be misleading and are thus excluded from the analysis.
} 
the global factor explains only a smaller part of these fluctuations. Baek (2006) shows that portfolio investment in Latin American economies seems to be pulled mainly by economic growth, while PI in Asian economies is primarily pushed by external factors. Similarly, Reinhart and Calvo (1996) find evidence of regional contagion effects on capital flows in Latin American countries. Overall, this literature suggests that our results would be more likely to hold in economies that are similar to Mexico in terms on macroeconomic conditions, institutions, risk assessment and geographic region, such as the Latin American economies. The specification used in the paper can also be applied to those and other economies. We leave this extension for future research.

\section{Conclusions}

Recent increases in capital flows can be explained by several factors. In this article, we studied the determinants of the dynamics for each component of the financial account for Mexico. The analysis is carried out via the estimation of impulse-response functions from a VAR model. The variables that represent push factors in this research are the global risk, the injection of liquidity, the FFR and U.S. GDP growth. Those factors had a statistically significant impact on several components of PI and OI to Mexico. We find that a shock to the FFR has an important and persistent impact on several items of the financial account. Domestic conditions are also strong determinants of capital flows, which is in line with Dooley (1988). For instance, we find that higher GDP growth generates higher PI, while higher interest rates and lower inflation lead to higher flows of OI.

From the estimation for aggregate categories, we find that an increase in global risk has a negative effect on PI, and a rise in global liquidity has a positive contemporaneous impact on PI. The results for Mexico are consistent with Fratzscher (2012), who notes that changes in global liquidity and risk have an important effect on capital flows. Although push factors are more difficult to control by policymakers, our results suggest that it is important to monitor external conditions to anticipate their effects on capital flows. Nevertheless, our results imply that monetary policy can influence OI, particularly in public sector securities. Similarly, our findings indicate that policies that affect exchange rates can have important effects on PI, OI and FDI.

From the disaggregated analysis, the response of a shock to the FFR, global risk, global liquidity, domestic GDP growth, domestic inflation, domestic interest rate and the exchange rate seems to have statistically significant effects on several items of the financial account, as opposed to the responses of net flows. These results support the importance of analysing capital flows at a higher degree of disaggregation than has been commonly used in the literature. For instance, we find that a shock to the FFR has important effects on PI in public sector securities by foreign residents.

From a policy point of view, the results presented in this paper for disaggregated categories can be useful to anticipate the specific types of capital flows that will be affected when different shocks occur. In particular, our results indicate that the holdings of private sector securities by foreigners decrease after a rise in global uncertainty, but their holdings of public sector securities present an opposite response. This can occur if investors prefer lower-risk securities after the shock in global uncertainty. 
Furthermore, we find that foreign investors respond to a higher extent to shocks in foreign interest rates and foreign liquidity compared to domestic investors. Finally, our results suggest that shocks to U.S. and domestic interest rates have important effects on the demand for public sector securities.

Our results are, of course, conditional on our empirical model and the sample period used. Further research could examine alternative identification assumptions such as imposing sign restrictions as an alternative strategy to identify the shocks. Other steps in the research agenda could include estimating a model with time-varying parameters to examine whether the determinants of capital flows have changed over time. In addition, future research could analyse the impact of capital flows on economic growth and stability.

Acknowledgements Open access funding provided by International Institute for Applied Systems Analysis (IIASA).

Funding Funding was provided by Consejo Nacional de Ciencia y Tecnología (Grant Nos. 2016-2018, $\mathrm{SNI})$.

Open Access This article is distributed under the terms of the Creative Commons Attribution 4.0 International License (http://creativecommons.org/licenses/by/4.0/), which permits unrestricted use, distribution, and reproduction in any medium, provided you give appropriate credit to the original author(s) and the source, provide a link to the Creative Commons license, and indicate if changes were made.

\section{References}

Ahmed S, Zlate A (2014) Capital flows to emerging market economies: a brave new world? J Int Money Finance 48:221-248

Baek IM (2006) Portfolio investment flows to Asia and Latin America: pull, push or market sentiment? J Asian Econ 17(2):363-373

Banco de México (2016). http://www.banxico.org.mx/. Accessed 22 Jan 2016

Bernanke BS, Reinhart VR (2004) Conducting monetary policy at very low short-term interest rates. Am Econ Rev 94(2):85-90

BIS (2018) BIS data: Global liquidity indicators. https://www.bis.org/statistics/gli.htm

Blanchard OJ, Quah D (1989) The dynamic effects of aggregate demand and supply disturbances. Am Econ Rev 79(4):655-673

Bohn H, Tesar LL (1996) US equity investment in foreign markets: portfolio rebalancing or return chasing? Am Econ Rev 86(2):77-81

Broner F, Didier T, Erce A, Schmukler SL (2013) Gross capital flows: dynamics and crises. J Monet Econ 60(1):113-133

Bruno V, Shin HS (2015) Cross-border banking and global liquidity. Rev Econ Stud 82(2):535-564

Calvo GA, Leiderman L, Reinhart CM (1993) Capital inflows and real exchange rate appreciation in Latin America: the role of external factors. Staff Pap Int Monet Fund 40(1):108-151

Calvo GA, Leiderman L, Reinhart CM (1996) Inflows of capital to developing countries in the 1990 s. J Econ Perspect 10(2):123-139

Chiquiar D, Tobal M (2016) La voz de los emergentes y el ciclo financiero global. http://focoeconomico. org/2016/06/06/la-voz-de-los-emergentes-y-el-ciclo-financiero-global/. Accessed 6 June 2016

Chiquiar D, Tobal M (2017) Brecha del producto y ciclo financiero global. http://focoeconomico.org/2017/ 04/11/brecha-del-producto-y-ciclo-financiero-global/. Accessed 11 Apr 2017

Chuhan P, Claessens S, Mamingi N (1998) Equity and bond flows to Latin America and Asia: the role of global and country factors. J Dev Econ 55(2):439-463

Çulha A (2006) A structural VAR analysis of the determinants of capital flows into Turkey. Cent Bank Rev 2(2):11-35 
De Gregorio J, Edwards S, Valdes RO (2000) Controls on capital inflows: do they work? J Dev Econ 63(1):59-83

De Vita G, Kyaw KS (2008) Determinants of capital flows to developing countries: a structural VAR analysis. Rev Econ Stud 35(4):304-322

Dooley MP (1988) Capital flight: a response to differences in financial risks. Staff Pap Int Monet Fund 35(3):422-436

Edison HJ, Reinhart CM (2000) Capital controls during financial crises: the case of Malaysia and Thailand. In: Glick R (ed) Financial crises in emerging markets. Cambridge University Press, Cambridge, pp $427-456$

Eichengreen BJ, Gupta PD (2016) Managing sudden stops. The World Bank policy research working paper $7639, \mathrm{p} 37$

Fernandez-Arias E (1996) The new wave of private capital inflows: push or pull? J Dev Econ 48(2):389-418

Forbes KJ, Warnock FE (2012) Capital flow waves: surges, stops, flight, and retrenchment. J Int Econ 88(2):235-251

Förster M, Jorra M, Tillmann P (2014) The dynamics of international capital flows: results from a dynamic hierarchical factor model. J Int Money Finance 48:101-124

Fratzscher M (2012) Capital flows, push versus pull factors and the global financial crisis. J Int Econ 88(2):341-356

García-Padilla JR (2014) Secondary market. In: JJ Cortina-Morfin, C Álvarez-Toca (Eds) The Mexican government securities market. http://www.banxico.org.mx/elib/mercado-valores-gub-en/OEBPS/ Text/default.html. Accessed 11 Apr 2017

IMF (2003) Balance of payments manual, 5th edn

Lensink R, White H (1998) Does the revival of international private capital flows mean the end of aid? An analysis of developing countries access to private capital. World Dev 26(7):1221-1234

Milesi-Ferretti GM, Tille C (2011) The great retrenchment: international capital flows during the global financial crisis. Econ Policy 26(66):289-346

Montiel P, Reinhart CM (1999) Do capital controls and macroeconomic policies influence the volume and composition of capital flows? Evidence from the 1990s. J Int Money Finance 18(4):619-635

Murno J (2016) EMTA survey: quarterly emerging markets debt trading at US\$1.379 trillion. OECD, New York

OECD (2013a) Benchmark definition of foreign direct investment, 4th edn

OECD (2013b) OECD international direct investment statistics

Reinhart CM, Calvo S (1996) Capital flows to Latin America: is there evidence of contagion effects? In: Calvo GA, Goldstein M, Hochreiter E (eds) Private capital flows to emerging markets after the Mexican crisis. Peterson Institute Press, Washington, pp 151-171

UNCTAD (2013) World investment prospects survey, 2013-2015. United Nations, New York

UNCTAD (2015) World investment report of the United Nations conference on trade and development

Wu JC, Xia FD (2016) Measuring the macroeconomic impact of monetary policy at the zero lower bound. J Money Credit Bank 48(2-3):253-291

Ying YH, Kim Y (2001) An empirical analysis on capital flows: the case of Korea and Mexico. South Econ J 67(4):954-968

Publisher's Note Springer Nature remains neutral with regard to jurisdictional claims in published maps and institutional affiliations.

\section{Affiliations}

\section{Raul Ibarra ${ }^{3}$ Isela-Elizabeth Tellez-Leon ${ }^{1,2}$}

Raul Ibarra

ribarra@banxico.org.mx

1 Cross-Cutting Project, Systemic Risk and Network Dynamics, International Institute for Applied Systems Analysis, Laxenburg, Austria 
2 Advanced Systems Analysis (ASA), Evolution and Ecology (EEP) and Risk and Resilience (RISK), International Institute for Applied Systems Analysis, Laxenburg, Austria

3 Banco de México, Dirección General de Investigación Económica, Av. 5 de Mayo 18, Centro, Mexico City 06059, Mexico 